Hydrology and Earth System Sciences, 6(3), 559-582 (2002) C C EGS

\title{
A nitrogen model for European catchments: INCA, new model structure and equations
}

\author{
A.J. Wade ${ }^{1}$, P. Durand ${ }^{2}$, V. Beaujouan ${ }^{2}$, W.W. Wessel ${ }^{3}$, K.J. Raat ${ }^{3}$, P.G. Whitehead ${ }^{1}$, \\ D. Butterfield ${ }^{1}$, K. Rankinen ${ }^{4}$ and A. Lepisto ${ }^{4}$ \\ ${ }^{1}$ Aquatic Environments Research Centre, Department of Geography, University of Reading, Reading, RG6 6AB, UK \\ ${ }^{2}$ USARQ-Institut National de la Recherche Agronomique, Centre de Rennes, 65 rue de St Brieuc, CS 84215, 35042 Rennes, France \\ ${ }^{3}$ Universiteit van Amsterdam, IBED - Physical Geography, Nieuwe Achtergracht 166, 1018 WV Amsterdam, The Netherlands \\ ${ }^{4}$ Finnish Environment Institute, Impacts Research Division, PO Box 140, Kesäkatu 6, FIN-00251, Helsinki, Finland
}

Email for corresponding author: andrew.wade4@btinternet.com

\begin{abstract}
A new version of the Integrated Nitrogen in Catchments model (INCA) was developed and tested using flow and streamwater nitrate concentration data collected from the River Kennet during 1998. INCA is a process-based model of the nitrogen cycle in the plant/soil and instream systems. The model simulates the nitrogen export from different land-use types within a river system, and the in-stream nitrate and ammonium concentrations at a daily time-step. The structure of the new version differs from the original, in that soil-water retention volumes have been added and the interface adapted to permit multiple crop and vegetation growth periods and fertiliser applications. The process equations are now written in terms of loads rather than concentrations allowing a more robust tracking of mass conservation when using numerical integration. The new version is able to reproduce the seasonal dynamics observed in the streamwater nitrogen concentration data, and the loads associated with plant/soil system nitrogen processes reported in the literature. As such, the model results suggest that the new structure is appropriate for the simulation of nitrogen in the River Kennet and an improvement on the original model. The utility of the INCA model is discussed in terms of improving scientific understanding and catchment management.
\end{abstract}

Keywords: modelling, water quality, nitrogen, nitrate, River Kennet, River Thames

\section{Introduction}

In Europe, some water quality problems in river systems are directly associated with nitrogen $(\mathrm{N})$ pollution; these include eutrophication caused by agricultural runoff, $\mathrm{N}$ saturation in forest areas and soil and streamwater acidification, the latter two being linked to atmospheric $\mathrm{N}$ deposition. There are also indirect effects on the water quality associated with climate change and climate variability which affect the distribution of high and low flow extremes and it is under high and low flow conditions when acidification and eutrophication, respectively, are greatest. The effects of each $\mathrm{N}$ problem may be spatially localised, though larger $\left(>100 \mathrm{~km}^{2}\right)$ river basins may encompass areas subject to more than one form of $\mathrm{N}$ pollution. For example, the River Dee in North East Scotland is sensitive to changes in both atmospheric and agricultural $\mathrm{N}$ sources (Wade et al., 2001).
Mathematical models that simulate and predict nitrogen transport and retention within European catchments are required for the abatement and prevention of $\mathrm{N}$ pollution (Neal et al., 2002). In particular, there is a need for models that integrate the effects of point and diffuse $\mathrm{N}$ sources, to estimate the likely impacts on the river and groundwater systems of current and future land management, and climatic variability (Wade et al., 2002). Depending on the objectives of the modelling exercise, the spatial and temporal scale of interest will necessarily vary. Typically, using a model to investigate the main processes controlling the $\mathrm{N}$ cycle in a particular system requires investigations on small catchments, usually around $1 \mathrm{~km}^{2}$; at that spatial scale, investigations of water flow-path controls on $\mathrm{N}$ transfer requires within-storm or seasonal observations, whereas forest $\mathrm{N}$ saturation tends to be studied at the seasonal to decadal scale. When a model is used to test different 
scenarios of interest to policy makers, such as the impact of $\mathrm{N}$ emission reductions or of Common Agricultural Policy (CAP) changes on $\mathrm{N}$ loads in streams, both spatial and temporal scales of interest are likely to be larger (over $100 \mathrm{~km}^{2}$ and decadal to centurial, respectively).

The Integrated Nitrogen in Catchments model (INCA) was one of the first models to simulate the integrated effects of point and diffuse $\mathrm{N}$ sources on streamwater nitrate $\left(\mathrm{NO}_{3}\right)$ and ammonium $\left(\mathrm{NH}_{4}\right)$ concentrations and loads, and to estimate $\mathrm{N}$ process loads in the plant/soil system (Whitehead et al., 1998a). Since INCA is based on mass-balance, it is potentially applicable to a broad range of spatial and temporal scales, yet until recently the applications of INCA have been limited to relatively large river systems of around 1000-2000 km², all within the UK (Whitehead et al., 1998b, 2002; Wade et al., 2001). Thus, to develop INCA further as a tool for aiding scientific understanding and catchment management, work was done to apply INCA to a variety of river and groundwater systems throughout Europe, covering spatial scales from 0.005 to $4000 \mathrm{~km}^{2}$ (Wade et al., 2002). The results of the preliminary stages of this work highlighted the need for changes to the model structure, necessary to make INCA more generally applicable. The objective of this paper is to report the changes made and to provide initial verification that these resulted in improved model performance. Specifically, the paper:

1. describes the new model equations;

2. reports the performance comparison between the old (version 1.0) and new (version 1.6) INCA structures when applied to a well-researched, agriculturally impacted, permeable catchment, the Kennet, that is characteristic of much of lowland UK (Neal et al., 2002);

3. demonstrates the utility of the model for improving understanding of river system functioning.

\section{The Kennet System and the Database}

\section{STUDY AREA}

The River Kennet (c. $\left.1200 \mathrm{~km}^{2}\right)$ is typical of Cretaceous Chalk catchments in southern England (Fig. 1). Rising from a source at $190 \mathrm{~m}$, the Kennet flows broadly eastwards for c. $40 \mathrm{~km}$ before entering the River Thames at Reading. Cretaceous Chalk covers approximately $80 \%$ of the total area and forms a major aquifer, providing a water source for drinking, domestic and agricultural use. The relief is dominated by gently sloping valleys, with the altitudinal range spanning $32 \mathrm{~m}$ at the confluence with the Thames to $294 \mathrm{~m}$ at the highest point on the Marlborough Downs. The Kennet has two major tributaries: the Lambourn and the Enbourne.

The long-term annual precipitation over the catchment is $774 \mathrm{~mm}$, with approximately $38 \%$ ultimately apportioned to river flow and $62 \%$ to evapotranspiration (NERC, 1998). Much of the precipitation percolates into the Chalk aquifer, and consequently the flow response in streams is highly damped (except for the Tertiary Clay-lined Enbourne tributary). The long-term annual mean flow at Theale, the lowest gauging station on the Kennet, is $9.6 \mathrm{~m}^{3} \mathrm{~s}^{-1}$ (or $294 \mathrm{~mm}$ of runoff; NERC, 1998). The catchment is mainly rural, with arable agriculture being the predominant land use. There are four towns along the main channel: Marlborough in the upper reaches, Hungerford and Newbury in the mid-section and Reading which is located on the confluence between the Kennet and the Thames (Fig. 1). Hence treated sewage and industrial effluent is discharged directly into the Kennet. The catchment provides water for public and industrial supply by means of direct surface and groundwater abstractions.

The upper River Kennet is designated a Site of Special Scientific Interest (SSSI), in recognition of its outstanding chalk river plant and animal communities and, therefore, there is keen interest in protecting the high conservation value of the river. In the last decade, there have been increasing concerns about perceived ecological deterioration, particularly poor growth of Ranunculus downstream of Marlborough, accompanied by unsightly growth of epiphytes (Wright, 2002). Concerns have focused on the protracted droughts that occurred in 1991-2 and 1996-7, on water abstraction pressures and on declines in water quality associated with reduced capacity for dilution of effluent from Marlborough Sewage Treatment Works (STW) (Neal et al., 2002).

Weekly water samples were taken from seven sites upstream of Knighton gauging station between January and December 1998 as part of a much larger sampling programme, designed primarily to assess the impact of point and diffuse sources of phosphorus on water quality functioning and river ecology (Jarvie et al., 2002a, Fig. 1.) The water quality samples were analysed for $\mathrm{NO}_{3}$ and $\mathrm{NH}_{4}$, amongst a broad range of determinands. Monthly $\mathrm{NO}_{3}$ and $\mathrm{NH}_{4}$ concentration data were also available from 13 Environment Agency (EA) routine monitoring sites along the main stem of the Kennet. These, and other data required for the model application, are described in more detail later in the section, Model Set-up and Application.

Nitrogen is highly mobile within the catchment and is transported largely in solution as $\mathrm{NO}_{3}$. This means that $\mathrm{NO}_{3}$ 


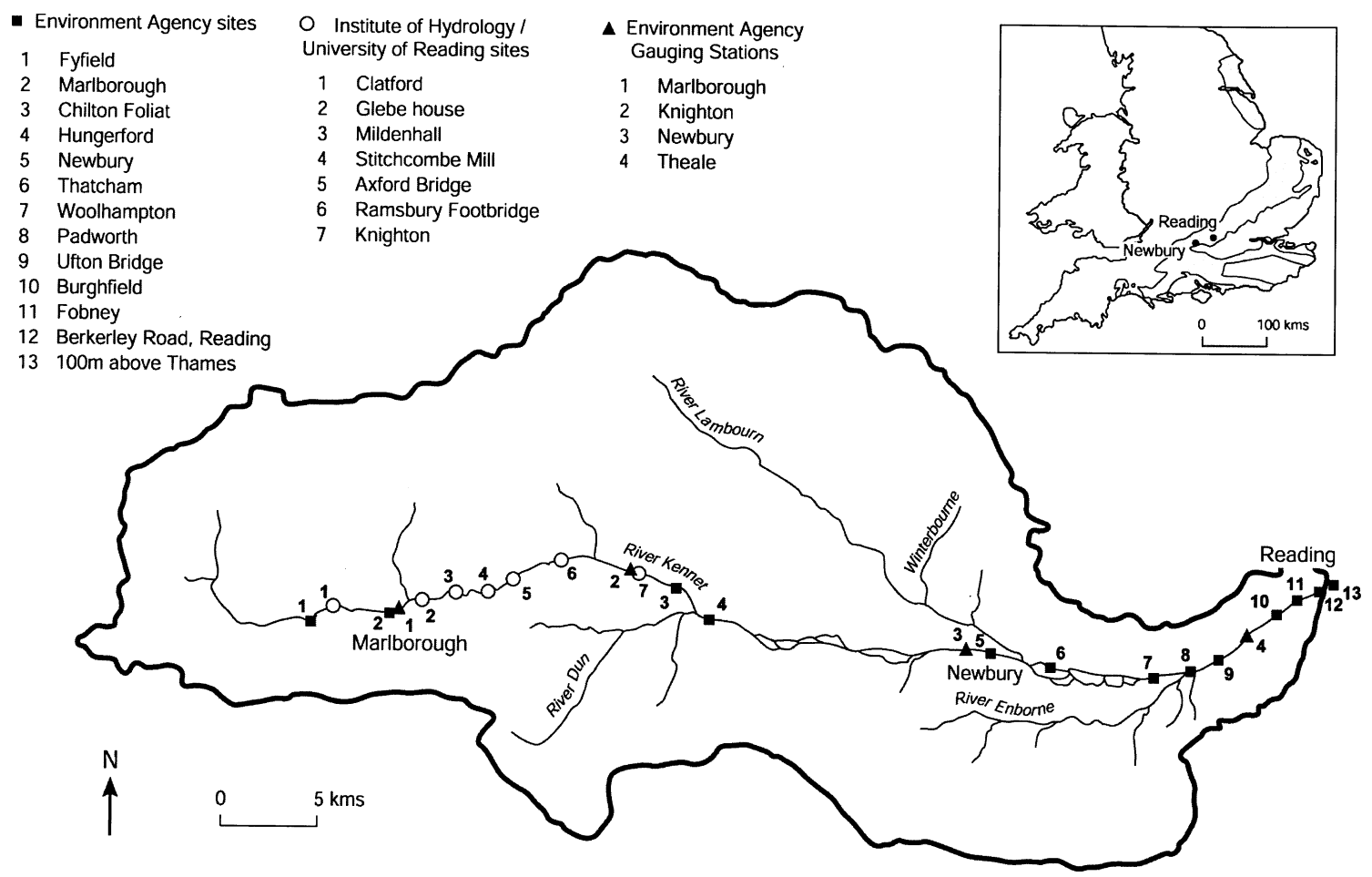

Fig. 1. The River Kennet catchment. The inset map shows the location of Cretaceous Chalk in England.

is readily leached into the groundwater and ultimately into streamflow (Neal et al., 2002). Analysis of the water quality data shows that arable agriculture is a major source of $\mathrm{NO}_{3}$ in the Kennet system, and the mean streamwater $\mathrm{NO}_{3}$ concentration is around 6 and $4 \mathrm{mg} \mathrm{N}^{-1}$ in the upper and lower reaches of the Kennet, respectively. In general, the relationship between flow and streamwater $\mathrm{NO}_{3}$ concentrations is weak, reflecting the bias to sampling under baseflow conditions and the many hydrological and biogeochemical processes that affect the streamwater $\mathrm{NO}_{3}$ concentrations. In both the upper and lower reaches, the hydrological and biogeochemical effects are integrated with those caused by land management practices. Fertilisers are applied to the land in winter and early spring, and the $\mathrm{NO}_{3}$ concentrations in the river reach a maximum of around $9 \mathrm{mg} \mathrm{N}^{-1}$ at this time, due probably to the $\mathrm{NO}_{3}$ leaching from water saturated soils and fertiliser additions. During summer and early autumn, the streamwater $\mathrm{NO}_{3}$ concentrations reach a minimum of around $3 \mathrm{mg} \mathrm{N}^{-1}$ due to seasonal plant uptake. In the lower reaches, the seasonal pattern is less pronounced as inputs from the STW cause higher streamwater $\mathrm{NO}_{3}$ concentrations during the summer due to reduced dilution.

Long-term water quality data for the River Thames at Teddington reveal a three-fold increase in $\mathrm{NO}_{3}$ concentrations since the 1930 s, an increase that was also simulated by an Export Co-efficient Model when applied to the Kennet catchment (Whitehead et al., 2002). In both cases, the increased $\mathrm{NO}_{3}$ concentrations have been linked to increased fertiliser applications associated with intensified cereal production, population growth and increased livestock levels.

\section{Model Structure}

Whilst testing the original version of INCA (v1.0), errors were found with the calculations of the soil, groundwater and streamwater concentrations. These errors arose because:

1. the changes in the hydrological storage volume were not calculated explicitly;

2. in the numerical solution of the differential equations, the change in $\mathrm{N}$ concentration was evaluated independently of the water volume stored;

3. the $\mathrm{N}$ concentration was dependent on the $\mathrm{N}$ mass output; however, the system $\mathrm{N}$ concentration need not change with water outflow.

Re-writing the model equations in terms of $\mathrm{N}$ mass and water volume, rather than using concentrations, corrected these errors, though the new version of INCA retains the key features of the original: the spatial characterisation of $\mathrm{N}$ 
input variations with land use and a concentration dependency of the $\mathrm{N}$ transformation rates in the plant/soil system and in-stream. The numerical method for solving the equations is still based on the fourth-order Runge-Kutta technique, since this allows a simultaneous solution of the model equations and thereby ensures that no single process, represented by the equations, takes precedence over another. The new model equations are described later, the nomenclature is summarised in Tables 1 to 5 and the equations used to verify the mass-balance within the land and in-stream components are presented in Appendices A and $\mathrm{B}$, respectively.

The key processes and $\mathrm{N}$ transformations assumed to occur in the plant/soil system are shown in Fig. 2. The processes simulated in the new and old versions are the same, the change being in the factors on which the processes depend (Eqns. 12 to 17). As such, INCA (v1.6) models plant uptake of $\mathrm{NO}_{3}$ and $\mathrm{NH}_{4}$, nitrification, denitrification, mineralisation and immobilisation within each land-use type within each sub-catchment. These processes are represented by a generalised set of six equations; one set to simulate the flow and $\mathrm{N}$ in a $1 \mathrm{~km}^{2}$ cell in each of six land-use types. Parameter sets for the equations are derived through calibration, the process whereby the model parameters are adjusted until the difference between observed and simulated data is considered acceptable (Oreskes et al., 1994).
The soil reactive zone is assumed to leach water to the deeper groundwater zone and the river. In the groundwater zone, it is assumed that no biogeochemical reactions occur and that a mass balance of $\mathrm{NH}_{4}$ and $\mathrm{NO}_{3}$ is adequate. The split between the volume of water stored in the soil and the groundwater is calculated using the Base Flow Index, which is an attempt to estimate the proportions of water in a stream derived from surface and deeper groundwater sources. Whilst the index is an over-simplification, since rapid stormflow does not comprise soil water only, it represents a pragmatic method for achieving such a split and is based on the analysis of observed river flows in the UK (Gustard et al., 1987).

The major change in the model structure is the addition of retention volumes, a feature designed to allow the simulation of long-term changes in the water and $\mathrm{N}$ stored in the soil. In the original version of INCA v1.0, the water storage volume within a catchment depended only on the rainfall input. This was an over-simplification, as it is known that water can be retained both in a catchment's soil and groundwater. The most serious implication of this original INCA representation was that a large volume of water, and therefore $\mathrm{N}$ mass, was unaccounted for. In particular, the damped stream response to $\mathrm{N}$ input variations and the long term accumulation and release observed in many catchments could not be simulated properly. Thus, soil and groundwater

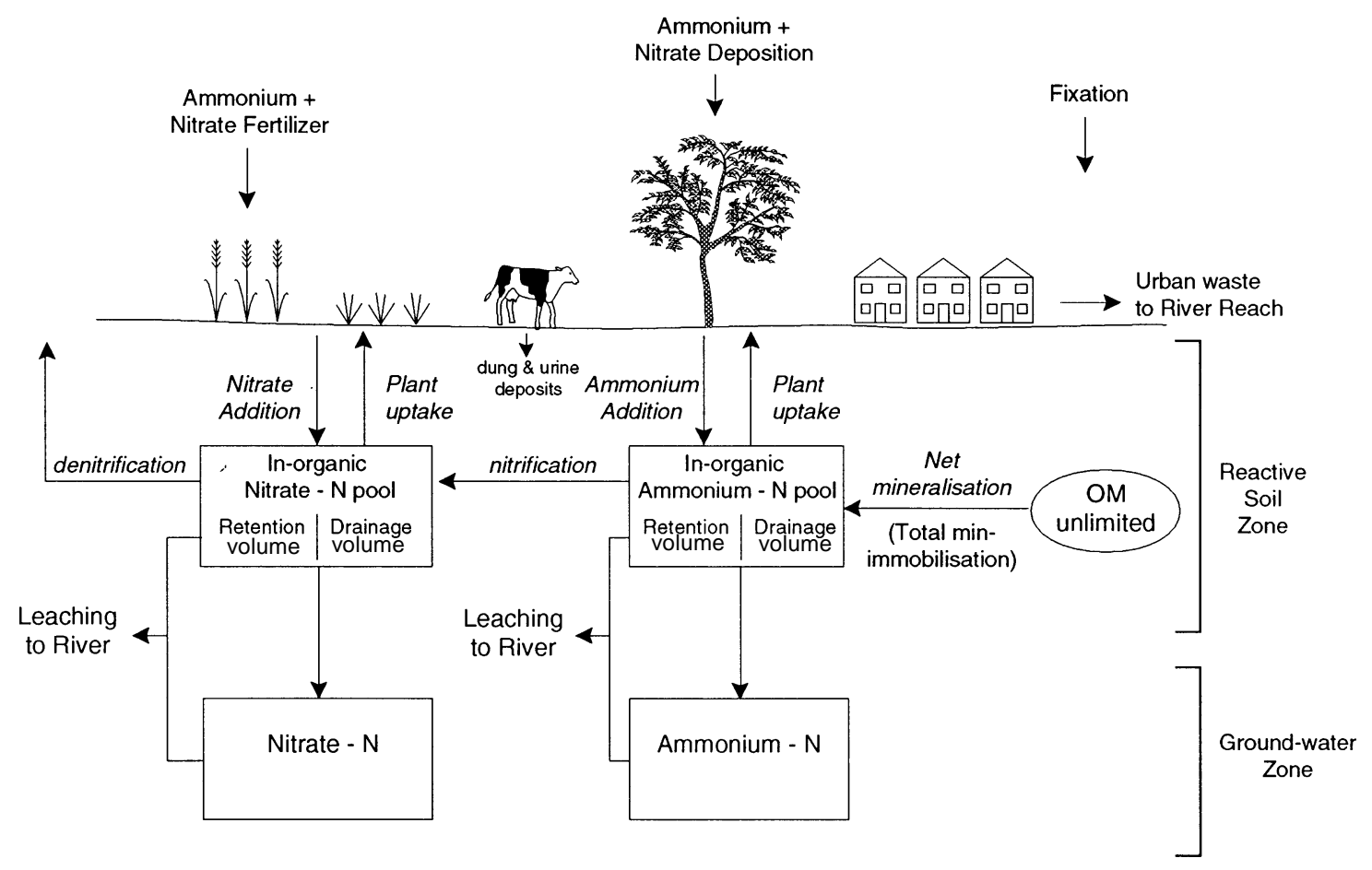

Fig. 2. The structure of the land component of the new version of INCA. 
Table 1. Variables in the land component equations.

\begin{tabular}{|c|c|c|}
\hline Symbol & Definition & Units \\
\hline $\mathrm{dx}_{1} / \mathrm{dt}$ & Change in soil flow & $\mathrm{m}^{3} \mathrm{~s}^{-1} \mathrm{day}^{-1} \mathrm{~km}^{-2}$ \\
\hline $\mathrm{dx}_{2} / \mathrm{dt}$ & Change in groundwater flow & $\mathrm{m}^{3} \mathrm{~s}^{-1} \mathrm{day}^{-1} \mathrm{~km}^{-2}$ \\
\hline $\mathrm{dx}_{3} / \mathrm{dt}$ & Change in soil Nitrate mass & $\mathrm{kg} \mathrm{N}$ day $^{-1} \mathrm{~km}^{-2}$ \\
\hline $\mathrm{dx}_{4}^{3} / \mathrm{dt}$ & Change in groundwater Nitrate mass & $\mathrm{kg} \mathrm{N}$ day ${ }^{-1} \mathrm{~km}^{-2}$ \\
\hline $\mathrm{dx}_{5}^{4} / \mathrm{dt}$ & Change in soil Ammonium mass & $\mathrm{kg} \mathrm{N}$ day ${ }^{-1} \mathrm{~km}^{-2}$ \\
\hline $\mathrm{dx}^{5} / \mathrm{dt}$ & Change in groundwater Ammonium mass & $\mathrm{kg} \mathrm{N}$ day ${ }^{-1} \mathrm{~km}^{-2}$ \\
\hline $\mathrm{dx}_{7} / \mathrm{dt}$ & Gross input rate of Nitrate mass into the system & $\mathrm{kg} \mathrm{N}$ day $^{-1} \mathrm{~km}^{-2}$ \\
\hline $\mathrm{dx}_{8} / \mathrm{dt}$ & Gross output rate of Nitrate mass from the system & $\mathrm{kg} \mathrm{N} \mathrm{day}^{-1} \mathrm{~km}^{-2}$ \\
\hline $\mathrm{dx}_{9}^{8} / \mathrm{dt}$ & Gross input rate of Ammonium mass into the system & $\mathrm{kg} \mathrm{N}$ day $^{-1} \mathrm{~km}^{-2}$ \\
\hline $\mathrm{dx}_{10} / \mathrm{dt}$ & Gross output rate of Ammonium mass output from the system & $\mathrm{kg} \mathrm{N}$ day ${ }^{-1} \mathrm{~km}^{-2}$ \\
\hline $\mathrm{dx}_{11} / \mathrm{dt}$ & Soil water volume change & $\mathrm{m}^{3} \mathrm{day}^{-1} \mathrm{~km}^{-2}$ \\
\hline $\mathrm{dx}_{12} / \mathrm{dt}$ & Groundwater volume change & $\mathrm{m}^{3}$ day ${ }^{-1} \mathrm{~km}^{-2}$ \\
\hline $\mathrm{dx}_{13}^{12} / \mathrm{dt}$ & Total water flow input to the system & $\mathrm{m}^{3}$ day ${ }^{-1} \mathrm{~km}^{-2}$ \\
\hline $\mathrm{dx}_{14}^{13} / \mathrm{dt}$ & Total water flow output from the system & $\mathrm{m}^{3} \mathrm{day}^{-1} \mathrm{~km}^{-2}$ \\
\hline $\mathrm{dx}_{15}^{14} / \mathrm{dt}$ & Change in nitrate plant-uptake & $\mathrm{kg} \mathrm{N}$ day $^{-1} \mathrm{~km}^{-2}$ \\
\hline $\mathrm{dx}_{16} / \mathrm{dt}$ & Change in denitrification & $\mathrm{kg} \mathrm{N}_{\text {day }}{ }^{-1} \mathrm{~km}^{-2}$ \\
\hline $\mathrm{dx}^{16} / \mathrm{dt}$ & Change in nitrification & $\mathrm{kg} \mathrm{N} \mathrm{day}^{-1} \mathrm{~km}^{-2}$ \\
\hline $\mathrm{dx}_{18}^{17} / \mathrm{dt}$ & Change in fixation & $\mathrm{kg} \mathrm{N} \mathrm{day}^{-1} \mathrm{~km}^{-2}$ \\
\hline $\mathrm{dx}_{19}^{18} / \mathrm{dt}$ & Change in ammonium plant-uptake & $\mathrm{kg} \mathrm{N}$ day $^{-1} \mathrm{~km}^{-2}$ \\
\hline $\mathrm{dx}_{20} / \mathrm{dt}$ & Change in immobilisation & $\mathrm{kg} \mathrm{N}$ day ${ }^{-1} \mathrm{~km}^{-2}$ \\
\hline $\mathrm{dx}_{21}^{20} / \mathrm{dt}$ & Change in mineralisation & $\mathrm{kg} \mathrm{N}$ day $^{-1} \mathrm{~km}^{-2}$ \\
\hline$x_{1}$ & Soil outflow & $\mathrm{m}^{3} \mathrm{~s}^{-1} \mathrm{~km}^{-2}$ \\
\hline $\begin{array}{ll}n_{1} \\
x_{2}\end{array}$ & Groundwater outflow & $\mathrm{m}^{3} \mathrm{~s}^{-1} \mathrm{~km}^{-2}$ \\
\hline$x_{3}^{2}$ & Nitrate stored in soil & $\mathrm{kg} \mathrm{N} \mathrm{km}^{-2}$ \\
\hline$x_{4}^{3}$ & Nitrate stored in groundwater & $\mathrm{kg} \mathrm{N} \mathrm{km}^{-2}$ \\
\hline $\mathrm{x}_{5}$ & Ammonium stored in soil & $\mathrm{kg} \mathrm{N} \mathrm{km}^{-2}$ \\
\hline$x_{6}^{3}$ & Ammonium stored in groundwater & $\mathrm{kg} \mathrm{N} \mathrm{km}^{-2}$ \\
\hline$x_{7}$ & Accumulated Nitrate input to the system since simulation start & $\mathrm{kg} \mathrm{N} \mathrm{km}^{-2}$ \\
\hline $\mathrm{x}_{8}$ & Accumulated Nitrate output from the system since simulation start & $\mathrm{kg} \mathrm{N} \mathrm{km}^{-2}$ \\
\hline$x_{9}$ & Accumulated Ammonium input to the system since simulation start & $\mathrm{kg} \mathrm{N} \mathrm{km}^{-2}$ \\
\hline $\mathrm{x}_{10}$ & Accumulated Ammonium output from the system since simulation start & $\mathrm{kg} \mathrm{N} \mathrm{km}^{-2}$ \\
\hline $\mathrm{x}_{11}$ & Soil water volume & $\mathrm{m}^{3} \mathrm{~km}^{-2}$ \\
\hline $\mathrm{x}_{12}$ & Groundwater volume & $\mathrm{m}^{3} \mathrm{~km}^{-2}$ \\
\hline $\mathrm{x}_{13}$ & Accumulated water input to the system since simulation start & $\mathrm{m}^{3} \mathrm{~km}^{-2}$ \\
\hline $\mathrm{x}_{14}$ & Accumulated water output from the system since simulation start & $\mathrm{m}^{3} \mathrm{~km}^{-2}$ \\
\hline $\mathrm{x}_{15}$ & Accumulated mass associated with nitrate plant-uptake & $\mathrm{kg} \mathrm{N} \mathrm{km}^{-2}$ \\
\hline $\mathrm{x}_{16}$ & Accumulated mass associated with denitrification & $\mathrm{kg} \mathrm{N} \mathrm{km}^{-2}$ \\
\hline $\mathrm{x}_{17}$ & Accumulated mass associated with nitrification & $\mathrm{kg} \mathrm{N} \mathrm{km}^{-2}$ \\
\hline $\mathrm{x}_{18}$ & Accumulated mass associated with fixation & $\mathrm{kg} \mathrm{N} \mathrm{km}^{-2}$ \\
\hline $\mathrm{x}_{19}$ & Accumulated mass associated with ammonium plant-uptake & $\mathrm{kg} \mathrm{N} \mathrm{km}^{-2}$ \\
\hline $\mathrm{x}_{20}$ & Accumulated mass associated with immobilisation & $\mathrm{kg} \mathrm{N} \mathrm{km}^{-2}$ \\
\hline $\mathrm{x}_{21}^{20}$ & Accumulated mass associated with mineralisation & $\mathrm{kg} \mathrm{N} \mathrm{km}^{-2}$ \\
\hline
\end{tabular}

Table 2. User supplied inputs as time series.

\begin{tabular}{lll}
\hline Symbol & Definition & Units \\
\hline $\mathrm{U}_{1}$ & Input hydrologically effective rainfall & $\mathrm{m}^{3} \mathrm{~s}^{-1} \mathrm{~km}^{-2}$ \\
$\mathrm{U}_{2}$ & Input Nitrate load (includes input from livestock, fertiliser and deposition) & $\mathrm{kg} \mathrm{N} \mathrm{ha}^{-1}$ day $^{-1}$ \\
$\mathrm{U}_{3}$ & Input Ammonium load (includes input from livestock, fertiliser and deposition) & $\mathrm{kg} \mathrm{N} \mathrm{ha}^{-1}$ day $^{-1}$ \\
$\mathrm{U}_{4}$ & Air temperature & ${ }^{\circ} \mathrm{C}$ \\
$\mathrm{U}_{5}$ & Soil Moisture Deficit & $\mathrm{mm}$ \\
$\mathrm{U}_{6}$ & Input precipitation & $\mathrm{mm}$ \\
\hline
\end{tabular}


Table 3. User supplied inputs as parameters in the land component equations.

\begin{tabular}{|c|c|c|}
\hline Symbol & Definition & Units \\
\hline$\hat{a}$ & Base Flow Index & $(\varnothing)$ \\
\hline $\mathrm{T}_{1}$ & Soil water residence time & days \\
\hline $\mathrm{T}_{2}$ & Groundwater residence time & days \\
\hline $\mathrm{C}_{1}$ & Denitrification rate & $\mathrm{m}$ day $^{-1}$ \\
\hline $\mathrm{C}_{2}$ & Fixation rate & $\mathrm{kg} \mathrm{N} \mathrm{ha}^{-1}$ day $^{-1}$ \\
\hline $\mathrm{C}_{3}$ & Plant nitrate-uptake rate & $\mathrm{m}$ day $^{-1}$ \\
\hline $\mathrm{C}_{4}$ & Nitrification rate & $\mathrm{m}$ day $^{-1}$ \\
\hline $\mathrm{C}_{5}$ & Mineralisation rate & $\mathrm{kg} \mathrm{N} \mathrm{ha}^{-1}$ day $^{-1}$ \\
\hline $\mathrm{C}_{6}$ & Immobilisation rate & $\mathrm{m}$ day $^{-1}$ \\
\hline $\mathrm{C}_{7}$ & Plant ammonium-uptake rate & $\mathrm{m}$ day $^{-1}$ \\
\hline $\mathrm{C}_{8}$ & Start of growing season & day number \\
\hline $\mathrm{C}_{9}^{0}$ & Maximum air temperature difference between summer and winter & ${ }^{\circ} \mathrm{C}$ \\
\hline$d$ & Depth of soil & $\mathrm{m}$ \\
\hline$p$ & Soil retention porosity & $(\varnothing)$ \\
\hline $\mathrm{x}_{3,0}$ & Initial nitrate stored in soil ${ }^{\mathrm{a}}$ & $\mathrm{kg} \mathrm{N} \mathrm{km}^{-2}$ \\
\hline $\mathrm{x}_{4,0}$ & Initial ammonium stored in soil ${ }^{\mathrm{a}}$ & $\mathrm{kg} \mathrm{N} \mathrm{km}^{-2}$ \\
\hline $\mathrm{x}_{5,0}$ & Initial nitrate stored in groundwater ${ }^{\mathrm{a}}$ & $\mathrm{kg} \mathrm{N} \mathrm{km}^{-2}$ \\
\hline$x_{6,0}$ & Initial ammonium stored in groundwater ${ }^{\mathrm{a}}$ & $\mathrm{kg} \mathrm{N} \mathrm{km}^{-2}$ \\
\hline
\end{tabular}

${ }^{\mathrm{a}}$ The initial conditions within the model equations are in terms of $\mathrm{kg} \mathrm{N} \mathrm{km}^{-2}$. However, the user specifies the initial conditions in terms of $\mathrm{mg} \mathrm{N}^{-1}$, and these concentrations are converted to $\mathrm{kg} \mathrm{N} \mathrm{km}^{-2}$ in the model.

Table 4. Model outputs calculated within the land component of the INCA.

\begin{tabular}{|c|c|c|}
\hline Symbol & Definition & Units \\
\hline $\mathrm{S}_{1}$ & Soil moisture factor & $(\varnothing)$ \\
\hline $\mathrm{S}_{2}$ & Seasonal plant growth index & $(\varnothing)$ \\
\hline $\mathrm{S}_{3}$ & Soil temperature & $(\varnothing)$ \\
\hline $\mathrm{S}_{4}$ & Total flow input to a reach & $\mathrm{m}^{3} \mathrm{~s}^{-1}$ \\
\hline $\mathrm{S}_{5}$ & Total nitrate input to a reach & $\mathrm{kg} \mathrm{N}_{\mathrm{day}}{ }^{-1}$ \\
\hline $\mathrm{S}_{6}$ & Total ammonium input to a reach & $\mathrm{kg} \mathrm{N}_{\mathrm{day}}{ }^{-1}$ \\
\hline $\mathrm{SMD}_{\max }$ & Maximum value of input soil moisture deficit values & $\mathrm{mm}$ \\
\hline $\mathrm{V}_{\mathrm{r}}$ & Soil retention volume & $\mathrm{m}^{3} \mathrm{~km}^{-2}$ \\
\hline $\mathrm{V}_{\mathrm{r}, \max }$ & Maximum soil retention volume & $\mathrm{m}^{3} \mathrm{~km}^{-2}$ \\
\hline$a_{1}$ & Soil water nitrate concentration & $\operatorname{mg~N~} 1^{-1}$ \\
\hline$a_{2}$ & Soil water ammonium concentration & $\operatorname{mg~N~} 1^{-1}$ \\
\hline$a_{3}$ & Groundwater nitrate concentration & $\mathrm{mg} \mathrm{N} 1^{-1}$ \\
\hline$a_{4}$ & Groundwater ammonium concentration & $\operatorname{mg~N~} 1^{-1}$ \\
\hline
\end{tabular}

retention volumes were added to the model structure. To do this, the structure of the TNT model developed by Beaujouan et al. (2001) was used.

In the INCAv1.6 model, the soil drainage volume represents the water volume stored in the soil that responds rapidly to water inflow. As such, it may be thought of as macropore, drain or piston flow: the flow that most strongly influences a rising hydrograph limb. The soil retention volume represents the water volume stored in the soil that responds more slowly and may make up the majority of water storage in the soil, very similar to the field capacity concept. As such, this water may be thought of as stored in the soil micropores, and therefore dependent on the soil wetting and drying characteristics. The groundwater volume represents the sum of the mobile and immobile water stored in the aquifer, while the time constant used in the discharge 
Table 5. Variables $\left(\mathrm{x}_{22}\right.$ to $\left.\mathrm{x}_{33}\right)$, inputs $\left(\mathrm{U}_{4}, \mathrm{U}_{7}\right.$ to $\left.\mathrm{U}_{9}\right)$, output concentrations $\left(\mathrm{a}_{5}\right.$ and $\left.\mathrm{a}_{6}\right)$ and parameters used in the in-stream component of the INCA model.

The user supplies the input data as a daily time series, though in the case of the effluent inputs, average annual values can be used if no time series data are available. During model calibration, the model parameters are determined by the user.

\begin{tabular}{|c|c|c|}
\hline Symbol & Definition & Units \\
\hline $\mathrm{dx}_{22} / \mathrm{dt}$ & Change in the in-stream flow & $\mathrm{m}^{3} \mathrm{~s}^{-1} \mathrm{day}^{-1}$ \\
\hline $\mathrm{dx}_{23}^{22} / \mathrm{dt}$ & Change in the in-stream nitrate mass & $\mathrm{kg} \mathrm{N}$ day $^{-1}$ \\
\hline $\mathrm{dx}_{24}^{23} / \mathrm{dt}$ & Change in the in-stream ammonium mass & $\mathrm{kg} \mathrm{N}$ day $^{-1}$ \\
\hline $\mathrm{dx}_{2} / \mathrm{dt}$ & Gross input rate of Nitrate mass into the system & $\mathrm{kg} \mathrm{N}$ day $^{-1}$ \\
\hline $\mathrm{dx}_{26}^{23} / \mathrm{dt}$ & Gross output rate of Nitrate mass from the system & $\operatorname{kg~N}$ day $^{-1}$ \\
\hline $\mathrm{dx}_{2}^{26} / \mathrm{dt}$ & Gross input rate of Ammonium mass into the system & $\mathrm{kg} \mathrm{N}$ day $^{-1}$ \\
\hline $\mathrm{dx}_{28}^{27} / \mathrm{dt}$ & Gross output rate of Ammonium mass output from the system & $\operatorname{kg~N}$ day $^{-1}$ \\
\hline $\mathrm{dx}_{29}^{28} / \mathrm{dt}$ & Change reach volume & $\mathrm{m}^{3}$ day $^{-1}$ \\
\hline $\mathrm{dx}_{30}^{29} / \mathrm{dt}$ & Change in flow volume into reach & $m^{3}$ day $^{-1}$ \\
\hline $\mathrm{dx}_{31} / \mathrm{dt}$ & Change in flow volume out from reach & $\mathrm{m}^{3}$ day $^{-1}$ \\
\hline $\mathrm{dx}_{3} / \mathrm{dt}$ & Change in denitrification mass & $\mathrm{kg} \mathrm{N}$ day $^{-1}$ \\
\hline $\mathrm{dx}_{33}^{32} / \mathrm{dt}$ & Change in nitrification mass & $\mathrm{kg} \mathrm{N}$ day $^{-1}$ \\
\hline$x_{22}$ & Reach outflow & $\mathrm{m}^{3} \mathrm{~s}^{-1}$ \\
\hline $\mathrm{x}_{23}^{22}$ & Nitrate mass stored in reach & $\mathrm{kg} \mathrm{N}$ \\
\hline $\mathrm{x}_{24}$ & Ammonium mass stored in reach & $\operatorname{kg~N}$ \\
\hline $\mathrm{x}_{25}$ & Accumulated Nitrate input to the reach since simulation start & $\operatorname{kg~N}$ \\
\hline$x_{26}^{23}$ & Accumulated Ammonium input to the reach since simulation start & $\operatorname{kg~N}$ \\
\hline $\mathrm{x}_{27}^{26}$ & Accumulated Nitrate output from the reach since simulation start & $\mathrm{kg} \mathrm{N}$ \\
\hline $\mathrm{x}_{28}^{21}$ & Accumulated Ammonium output from the reach since simulation start & $\mathrm{kg} \mathrm{N}$ \\
\hline $\mathrm{x}_{29}$ & Volume stored in reach & $\mathrm{m}^{3}$ \\
\hline $\mathrm{x}_{30}$ & Accumulated water input to the system since simulation start & $\mathrm{m}^{3}$ \\
\hline$x_{31}^{30}$ & Accumulated water output from the system since simulation start & $\mathrm{m}^{3}$ \\
\hline$x_{32}$ & Accumulated mass associated with denitrification & $\mathrm{kg} \mathrm{N}$ \\
\hline $\mathrm{x}_{33}^{32}$ & Accumulated mass associated with nitrification & $\mathrm{kg} \mathrm{N}$ \\
\hline $\mathrm{U}_{4}$ & Air/Water temperature & ${ }^{\circ} \mathrm{C}$ \\
\hline $\mathrm{U}_{7}^{4}$ & Effluent inflow & $\mathrm{m}^{3} \mathrm{~s}^{-1}$ \\
\hline $\mathrm{U}_{8}^{\prime}$ & Effluent nitrate concentration & $\mathrm{mg} \mathrm{N} 1^{-1}$ \\
\hline $\mathrm{U}_{9}^{8}$ & Effluent ammonium concentration & $\operatorname{mg~N~} 1^{-1}$ \\
\hline$a_{5}$ & In-stream nitrate concentration & $\mathrm{mg} \mathrm{N} 1^{-1}$ \\
\hline$a_{6}$ & In-stream ammonium concentration & $\operatorname{mg~N} 1^{-1}$ \\
\hline $\mathrm{C}_{10}$ & In-stream denitrification rate & day $^{-1}$ \\
\hline $\mathrm{C}_{11}^{10}$ & In-stream nitrification rate & day $^{-1}$ \\
\hline $\mathrm{T}_{3}$ & Water residence time & days \\
\hline $\operatorname{area}_{i, j}$ & Area of land use, $i$ in sub-catchment, $j$ & $\mathrm{~km}^{2}$ \\
\hline $\mathrm{L}$ & Reach length & $\mathrm{m}$ \\
\hline $\mathrm{a}$ & Discharge-velocity parameter & $\mathrm{m}^{-2}$ \\
\hline $\mathrm{b}$ & Discharge-velocity parameter & $(\varnothing)$ \\
\hline
\end{tabular}

equation applies to the mobile water only.

The $\mathrm{NO}_{3}$ and $\mathrm{NH}_{4}$ mass-balance equations for the soil store have been changed to include the dependency on drainage and retention volumes. The soil water drainage volume, $x_{11}$ is calculated by integrating Eqn. (4), whereas the retention volume per $\mathrm{km}^{2}, V_{r}\left(\mathrm{~m}^{3} \mathrm{~km}^{-2}\right)$ is linearly dependent on the Soil Moisture Deficit, $\mathrm{U}_{5}(\mathrm{~mm})$ at time, $t$ such that:

$$
V_{r}=V_{r, \max }-U_{5} .1000
$$

where

$$
V_{r, \max }=d \times p \times 10^{6}
$$

The factor of $10^{6}\left(\mathrm{~m}^{2} \mathrm{~km}^{-2}\right)$ is included to maintain the dimensions of Eqn. (2) and the units of $V_{r, \max }$ are 
$\left(\mathrm{m}^{3} \mathrm{~km}^{-2}\right)$. For a $1 \mathrm{~km}^{2}$ cell, $V_{r}$ can be expressed as

$$
A \cdot V_{r}=A .\left(V_{r, \max }-U_{5} \cdot 1000\right)
$$

where $A$ is the cell area $\left(\mathrm{km}^{2}\right), A . V_{r \text { max }}$ is the maximum size of the retention volume $\left(\mathrm{m}^{3}\right), d$ is the soil depth $(\mathrm{m})$, and $p$ is the soil retention porosity (Ø). Note that $V_{r, \max } / 10^{6}$ is necessarily greater than or equal to $\mathrm{SMD}_{\max }$, the maximum soil moisture deficit used to compute the HER (hydrologically effective rainfall). It is usually considered that $\mathrm{SMD}_{\max }$ represents the "available soil moisture", i.e. the difference between water content at field capacity and at wilting point, whereas $V_{r \text { max }}$ includes water more strongly retained by the soil, beyond wilting point.

\section{LAND COMPONENT}

\section{Hydrological mass-balance}

The equations describing the flow change from soil and the groundwater are the same as those in the original model (Whitehead et al., 1998a).

$$
\begin{aligned}
& \frac{d x_{1}}{d t}=\frac{U_{1}-x_{1}}{T_{1}} \\
& \frac{d x_{2}}{d t}=\frac{\beta x_{1}-x_{2}}{T_{2}}
\end{aligned}
$$

where $x_{1}$ and $x_{2}$ are the outflows from the soil and groundwater stores $\left(\mathrm{m}^{3} \mathrm{~s}^{-1} \mathrm{~km}^{-2}\right) U_{1}$ is the HER input $\left(\mathrm{m}^{3} \mathrm{~s}^{-1} \mathrm{~km}^{-2}\right), \beta$ is the base flow index (Ø), and $T_{1}$ and $T_{2}$ are the time constants in the soil and groundwater stores respectively (days). Since the hydrological mass-balance equations are based on a $1 \mathrm{~km}^{2}$ cell, the output is multiplied by the land area within a sub-catchment to calculate the water volume entering the stream.

\section{NITROGEN MASS-BALANCE}

The change in $\mathrm{NO}_{3}$ mass in soil, $x_{3}\left(\mathrm{~kg} \mathrm{~N} \mathrm{~km}^{-2}\right)$ and groundwater, $x_{4}\left(\mathrm{~kg} \mathrm{~N} \mathrm{~km}^{-2}\right)$ stores are given by Eqns. (6) and (7), respectively

\section{Soil Store}

$$
\begin{aligned}
& \frac{d x_{3}}{d t}=U_{2} .100-\frac{x_{1} x_{3} .86400}{V_{r}+x_{11}}-C_{3} S_{1} S_{2} \frac{x_{3}}{V_{r}+x_{11}} 10^{6} \\
& +C_{4} S_{1} \frac{x_{5}}{V_{r}+x_{11}} 10^{6}-C_{1} S_{1} \frac{x_{3}}{V_{r}+x_{11}} 10^{6}+C_{2} .100
\end{aligned}
$$

Groundwater Store

$$
\frac{d x_{4}}{d t}=\frac{\beta x_{1} x_{3} .86400}{V_{r}+x_{11}}-\frac{x_{2} x_{4} \cdot 86400}{x_{12}}
$$

where $x_{5}$ is the $\mathrm{NH}_{4}$ mass in the soil store $\left(\mathrm{kg} \mathrm{N} \mathrm{km}^{-2}\right), U_{2}$ is the input rate of $\mathrm{NO}_{3}\left(\mathrm{~kg} \mathrm{~N} \mathrm{ha}^{-1} \mathrm{day}^{-1}\right), V_{r}$ and $x_{11}$ are the retention and drainage volumes in the soil $\left(\mathrm{m}^{3} \mathrm{~km}^{-2}\right)$, and $x_{12}$ is the groundwater drainage volume $\left(\mathrm{m}^{3} \mathrm{~km}^{-2}\right)$. The constants $C_{1}, C_{2}, C_{3}, C_{4}$ are the rates of denitrification $\left(\mathrm{m}\right.$ day $\left.^{-1}\right)$, non-biological fixation $\left(\mathrm{kg} \mathrm{N} \mathrm{ha}^{-1}\right.$ day $\left.^{-1}\right)$, plant $\mathrm{NO}_{3}$ uptake $\left(\mathrm{m} \mathrm{day}^{-1}\right)$ and nitrification $\left(\mathrm{m} \mathrm{day}^{-1}\right)$, respectively and $S_{1}$ and $S_{2}$ are the soil moisture factor and seasonal plant growth index. As with the hydrological massbalance equations, the $\mathrm{N}$ mass balance equations are based on a $1 \mathrm{~km}^{2}$ cell and, therefore, the output from the equations is multiplied by the land area within a sub-catchment to calculate the $\mathrm{N}$ mass entering a reach of the stream.

The change in $\mathrm{NH}_{4}$ mass in soil, $x_{5}$ and groundwater, $x_{6}$ stores $\left(\mathrm{kg} \mathrm{N} \mathrm{km}^{-2}\right)$ is given by Eqns. (8) and (9):

Soil Store

$$
\begin{aligned}
& \frac{d x_{5}}{d t}=U_{3} \cdot 100-\frac{x_{1} x_{5} \cdot 86400}{V_{r}+x_{11}}-C_{7} S_{1} S_{2} \frac{x_{5}}{V_{r}+x_{11}} 10^{6} \\
& -C_{4} S_{1} \frac{x_{5}}{V_{r}+x_{11}} 10^{6}-C_{5} S_{1} 100-C_{6} S_{1} \frac{x_{5}}{V_{r}+x_{11}} 10^{6}
\end{aligned}
$$

Groundwater Store

$$
\frac{d x_{6}}{d t}=\frac{\beta x_{1} x_{5} \cdot 86400}{V_{r}+x_{11}}-\frac{x_{2} x_{6} \cdot 86400}{x_{12}}
$$

where $U_{3}$ is the input rate of $\mathrm{NH}_{4}$ load $\left(\mathrm{kg} \mathrm{N} \mathrm{ha}^{-1}\right.$ day $\left.^{-1}\right)$. The constants $C_{5}, C_{6}, C_{7}$ are the rates of mineralisation $\left(\mathrm{kg} \mathrm{N} \mathrm{ha}^{-1}\right.$ day $\left.^{-1}\right)$, immobilisation $\left(\mathrm{m} \mathrm{day}^{-1}\right)$ and plant $\mathrm{NH}_{4}$-uptake $\left(\mathrm{m} \mathrm{day}{ }^{-1}\right)$ respectively.

All the rate co-efficients are temperature dependent

$$
C_{n}=C 1.047^{\left(S_{3}-20\right)}
$$

where $S_{3}$ is the soil temperature estimated from a seasonal relationship dependent on air temperature as follows

$$
S_{3}=U_{4}-C_{9} \sin \left(\frac{3 \pi d a y}{2.365}\right)
$$

where $U_{4}$ is the air temperature $\left({ }^{\circ} \mathrm{C}\right)$ and $C_{9}$ is the maximum temperature difference $\left({ }^{\circ} \mathrm{C}\right)$ between summer and winter conditions (Green and Harding, 1979). This relationship generates a seasonal pattern for each land use, which is controlled by the parameter $C_{9}$. 
Plant uptake now depends on Soil Moisture Deficit. Thus,

$$
\text { Uptake }=C_{n} S_{1} S_{2} \frac{x_{m}}{V_{r}+x_{11}} 10^{6}
$$

where $n=3$ or 7 and $m=3$ or 5 for $\mathrm{NO}_{3}$ and $\mathrm{NH}_{4}$, respectively and

$$
S_{1}=\frac{S M D_{\max }-U_{5}}{S M D_{\max }}
$$

where $U_{5}$ is the input soil moisture deficit time series (mm) and $S M D_{\max }$ is the maximum soil moisture deficit $(\mathrm{mm})$. The plant uptake also depends on the seasonal plant growth index that accounts for the temporal variations in solar radiation (Hall and Harding, 1993). The index is given by

$$
S_{2}=0.66+0.34 \sin \left(2 \pi \frac{\left(\text { day of } \cdot \text { year }-C_{8}\right)}{365}\right)
$$

where $C_{8}$ is the day number associated with the start of the growing season.

Nitrification and immobilisation now depend on the Soil Moisture Deficit since both depend upon the soil moisture (Alexander, 1961; Bowden, 1987). In the original version of INCA, denitrification was dependent on a soil moisture threshold, and denitrification was 0 below the threshold. In the new version, there is no threshold and denitirification increases with soil wetness (Groffman et al., 1996). Thus,

Nitrification $= \pm C_{4} S_{1} \frac{x_{5}}{V_{r}+x_{11}} 10^{6}$

Immobilisation $=-C_{8} S_{1} \frac{x_{5}}{V_{r}+x_{11}} 10^{6}$

Denitrification $=-C_{1} S_{1} \frac{x_{5}}{V_{r}+x_{11}} 10^{6}$

The concentrations in the stores $\left(\mathrm{mg} \mathrm{N}^{-1}\right)$ are calculated as follows;

$$
\begin{aligned}
& \mathrm{NO}_{3}: \\
& a_{1}=\frac{x_{3} \cdot 1000}{x_{11}+V_{r}}
\end{aligned}
$$

where $a_{1}$ is the soil water $\mathrm{NO}_{3}$ concentration $\left(\mathrm{mg} \mathrm{N}^{-1}\right), x_{3}$ is the $\mathrm{NO}_{3}$ mass stored in the soil $\left(\mathrm{kg} \mathrm{N} \mathrm{km}^{-2}\right)$, and $\left(x_{11}+V\right)$ is the soil water volume of the soil store $\left(\mathrm{m}^{3} \mathrm{~km}^{-2}\right)$, and the factor of 1000 converts the units to $\mathrm{mg} \mathrm{N}^{-1}$ in Eqn. (18). Similarly, for $\mathrm{NH}_{4}$ in the soil store;

$$
\begin{aligned}
& \mathrm{NH}_{4}: \\
& a_{2}=\frac{x_{5} \cdot 1000}{x_{11}+V_{r}}
\end{aligned}
$$

where $a_{2}$ is the soil water $\mathrm{NH}_{4}$ concentration $\left(\mathrm{mg} \mathrm{N}^{-1}\right)$.

For the groundwater store;

$\mathrm{NO}_{3}$ :

$$
a_{3}=\frac{x_{4} \cdot 1000}{x_{12}}
$$

where $a_{3}$ is the groundwater $\mathrm{NO}_{3}$ concentration $\left(\mathrm{mg} \mathrm{N}^{-1}\right)$.

$\mathrm{NH}_{4}$ :

$$
a_{4}=\frac{x_{6} \cdot 1000}{x_{12}}
$$

where $a_{4}$ is the groundwater $\mathrm{NH}_{4}$ concentration $\left(\mathrm{mg} \mathrm{N}^{-1}\right)$.

\section{In-stream component}

The new equations that represent the hydrological and $\mathrm{N}$ mass-balance in the stream are described in this section, and the processes included in the in-stream component are shown in Fig. 3. All the symbols are defined in Table 5.

\section{IN-STREAM EQUATIONS}

The reach time constant, $T_{3}$ (in days) is calculated using the same equation as in INCA v1.0:

$$
T_{3}=\frac{L}{a x_{22}^{b} .86400}
$$

where $L$ is the reach length, $x_{22}$ is the discharge from the reach, the 86400 is a factor to convert seconds to days and $a$ and $b$ are parameters relating the reach velocity to the discharge (Whitehead et al., 1998a). Thus in-stream flow change is calculated from the input-output mass balance such that

$$
\frac{d x_{22}}{d t}=\frac{\left(S_{4}-x_{22}\right)}{T_{3}}
$$

where $S_{4}$ is the flow entering the reach from upstream and from any effluent sources. The $\mathrm{NO}_{3}, x_{23}$ and $\mathrm{NH}_{4}$ mass stored, $x_{24}(\mathrm{~kg} \mathrm{~N})$ in the reach are given by the following equations

$$
\begin{aligned}
& \frac{d x_{23}}{d t}=S_{5}-\frac{x_{22} x_{23} .86400}{x_{29}}-\frac{C_{11} a_{5, t-1} x_{29}}{1000}+\frac{C_{10} a_{6, t-1} x_{29}}{1000} \\
& \frac{d x_{24}}{d t}=S_{6}-\frac{x_{22} x_{24} \cdot 86400}{x_{29}}-\frac{C_{10} a_{6, t-1} x_{29}}{1000}
\end{aligned}
$$

where $S_{5}$ is the input mass from upstream plus any inputs from STW, $x_{29}$ is the reach volume and $C_{10}$ and $C_{11}$ are the in-stream nitrification and denitrification rates respectively. 
Instream processes

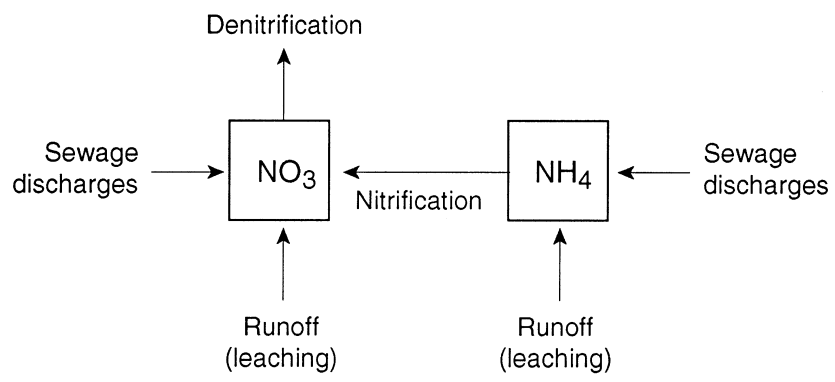

Multi-reach structure

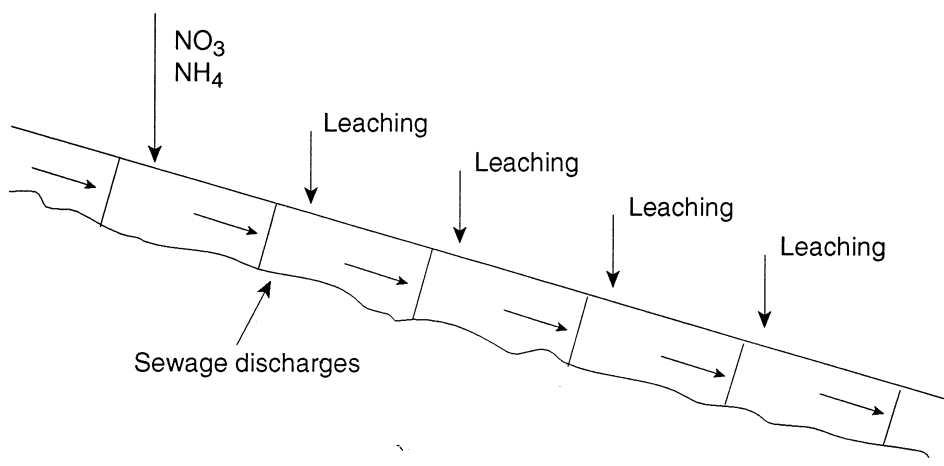

Fig. 3. The structure of the in-stream component of the new version of INCA. (After Whitehead et al., 1998a: published with permission of STOTEN, Elsevier).

For the stream component, the changes in the $\mathrm{NO}_{3}$ and $\mathrm{NH}_{4}$ mass within a reach due to nitrification and denitrification are a function of the streamwater $\mathrm{NO}_{3}$ and $\mathrm{NH}_{4}$ concentrations at the previous time step, $t-1$. Conceptually, this is less appealing than using the concentrations relating to the current time step, since the equations for a well-mixed cell suggest that the concentrations at the current time step should be used. However using the concentration at the last time step was found to be more stable during model runs, probably because the assumption is that the $\mathrm{NO}_{3}$ and $\mathrm{NH}_{4}$ concentrations vary only slowly and, therefore, the increased stability probably arises because the concentrations have effectively become constant for the duration of the time step. Further investigation is necessary to determine exactly the reasons for the increased stability, and the conditions when the equations can be written in terms of concentrations at time, $t$.

As in the land-component, the rate co-efficients are temperature dependent, such that

$$
C_{n}=C 1.047^{\left(U_{4}-20\right)}
$$

where $U_{4}$ is the water temperature, which is assumed to equal the input air temperature. It is recognised that there are more sophisticated methods for estimating water temperature, such as those based on air temperature, solar radiation and wind speed (Chapra, 1997). The simple approximation of equating water and air temperature was used to minimise the data requirements of INCA. If solar radiation and wind speed data were available, then a more sophisticated method could be incorporated into INCA. However introducing a more complex method would necessarily introduce more model parameters and therefore more uncertainty. Further research is required to determine the benefit of using a more complex water temperature model.

\section{INITIAL CONDITIONS}

To run the model, the initial water volumes and $\mathrm{N}$ loads are initialised using user-defined estimates of the river flow and the $\mathrm{NO}_{3}$ and $\mathrm{NH}_{4}$ concentrations in the furthest upstream reach of the system. The volume of the furthest upstream reach (1) was initialised using the following equation:

$$
x_{29,0,1}=T_{3,0} x_{22,0} 86400
$$

where $T_{3,0}$ and $x_{22,0}$ are the time constant and user-defined initial flow at time, $t=0$ in the furthest upstream reach, respectively with the time constant being determined from $x_{22,0}$ using Eqn. (22). 
The volume of the reach immediately downstream (2) was then initialised by running the model for the first time step, thereby integrating Eqn. (23) and adding the result to the $x_{29,0}$ :

$$
x_{29,0,2}=\left(S_{4,1}-x_{22,0,2}\right) 86400+x_{29,0,1}
$$

Each of the subsequent reaches was initialised in turn by integrating Eqn. (23) for the first time step and adding the result to upstream volume. Once all the reach volumes were initialised, then the model was reset to run from day 1 for calibration or scenario analysis. Thus, by using this process it is assumed that the reach volumes on day, $t=0$ are the same on day $t=1$. Whilst this is clearly an approximation, it is necessary to produce a model run.

The upstream $\mathrm{N}$ loads are calculated as follows. Input flow to a reach, $j$ from the total $n$ land use types, $i$

$$
S_{4, j}=U_{7, j}+\sum_{i=1}^{n} \operatorname{area}_{i, j}\left((1-\beta) x_{1}+x_{2}\right)
$$

where $\sum_{i=1}^{n} \operatorname{area}_{i, j}\left((1-\beta) x_{1}+x_{2}\right)$ is the flow input from land use type, $i$ into reach, $j$ and $U_{7}$ is the input from any STW in the reach.

Input $\mathrm{NO}_{3}$ load to a reach, $j$

$$
S_{5, j}=86.4\left(U_{7, j} U_{8, j}+\sum_{i=1}^{n} \operatorname{area}_{i, j}\left((1-\beta) x_{1} a_{1}+x_{2} a_{3}\right)\right)(30)
$$

Input $\mathrm{NH}_{4}$ load to a reach

$$
S_{6, j}=86.4\left(U_{7, j} U_{9, j}+\sum_{i=1}^{n} \operatorname{area}_{i, j}\left((1-\beta) x_{1} a_{2}+x_{2} a_{4}\right)\right)(31)
$$

\section{CALCULATION OF CONCENTRATIONS}

For the in-stream component model, the reach volume and the masses of $\mathrm{NO}_{3}$ and $\mathrm{NH}_{4}$ (Eqns. 23 to 25) are solved simultaneously. The in-stream $\mathrm{NO}_{3}$ and $\mathrm{NH}_{4}$ concentrations $\left(\mathrm{mg} \mathrm{N}^{-1}\right)$ are then determined from the resultant volume and $\mathrm{NO}_{3}$ and $\mathrm{NH}_{4}$ masses as follows;

$$
\begin{aligned}
& \mathrm{NO}_{3}: \\
& a_{5}=\frac{x_{23} \cdot 1000}{x_{29}}
\end{aligned}
$$

where $a_{5}$ is the in-stream $\mathrm{NO}_{3}$ concentration $\left(\mathrm{mg} \mathrm{N}^{-1}\right)$. $\mathrm{NH}_{4}$ :

$$
a_{6}=\frac{x_{24} \cdot 1000}{x_{29}}
$$

where $a_{6}$ is the in-stream $\mathrm{NH}_{4}$ concentration $\left(\mathrm{mg} \mathrm{N} \mathrm{l}^{-1}\right)$. The in-stream and land phase components operate in the same way. Namely, for the land phase, Eqns. (4) to (9) are solved simultaneously, and the concentrations (Eqns. 18 to 21) are evaluated from the resultant volumes and masses.

\section{Model set-up and application}

The purpose of applying the new version of the INCA model to the Kennet system was to compare the model results with those obtained from the original application, described in detail in Whitehead et al. (2002). Thus, the new version of INCA was applied using the same data as used in the original application, though additional data are required by the new version. The data used are described in this section, together with the calibration procedure.

\section{TEMPORAL INPUT DATA}

To drive the hydrological and $\mathrm{N}$ process component models, INCA requires time series inputs describing:

1. the hydrology: the HER, the actual rainfall, the soil moisture deficit and the air temperature;

2. the water chemistry: streamwater $\mathrm{NO}_{3}$ and $\mathrm{NH}_{4}(\mathrm{mg} \mathrm{N}$ $\left.1^{-1}\right)$ concentrations;

3. land management practices: the growing season for different crop and vegetation types, and fertiliser application quantities and timings;

4. sewage effluent flow rates and $\mathrm{NO}_{3}$ and $\mathrm{NH}_{4}$ concentrations ( $\mathrm{mg} \mathrm{N}^{-1}$ ) for the effluent;

5. wet and dry atmospheric deposition of $\mathrm{NO}_{3}$ and $\mathrm{NH}_{4}$ $\left(\mathrm{kg} \mathrm{N} \mathrm{ha}^{-1} \mathrm{yr}^{-1}\right)$.

The observed flow and water chemistry time-series were used for the purpose of model calibration. Daily flow data were available from four gauges along the main channel, maintained by the EA (Fig. 1). A comparison of the weekly streamwater $\mathrm{NO}_{3}$ concentrations determined by the Centre for Ecology and Hydrology, Wallingford (CEH), and the $\mathrm{NO}_{3}$ concentrations determined by the EA showed no obvious disparity, and therefore both sets of data were used to maximise the number of observations with which to calibrate and test INCA. Estimates of the annual average discharge and $\mathrm{NO}_{3}$ concentrations in effluent for nine STWs along the main stem were also available from Thames Water plc. The daily time series of HER, soil moisture deficit and air temperature data for 1998, used to drive the hydrological and $\mathrm{N}$ process components within INCA, were derived from the MORECS model (Hough et al., 1997), whilst the $a$ and $b$ parameters used to characterise the velocity-flow relationship in Eqn. (22) were derived for the original INCA application.

The daily actual precipitation time series was included to simulate the amount and timing of the wet and dry deposition inputs (Appendix C). Dry deposition was assumed to 
accumulate on leaves, and to be washed onto the soil during rainfall events rather than deposited on the soil surface directly. Estimates of the wet and dry deposition of oxidised and reduced $\mathrm{N}\left(\mathrm{NO}_{\mathrm{x}}\right.$ and $\left.\mathrm{NH}_{\mathrm{y}}\right)$ were derived from the MATADOR-N model (Model of Atmospheric Transport and Deposition Of Reacting Nitrogen, Rodgers 1993; RGAR, 1997). Based on 1994 meteorological and emission data, MATADOR-N estimated that over the Kennet catchment, the mean annual total (wet + dry) deposition of $\mathrm{N}\left(\mathrm{NO}_{3}+\right.$ $\mathrm{NH}_{4}$ ) was 14 and $22 \mathrm{~kg} \mathrm{~N} \mathrm{ha}^{-1} \mathrm{yr}^{-1}$ in the upper and lower reaches of the Kennet catchment, respectively.

The fertiliser sub-model used in INCA (v1.0) has been removed and in INCA (v1.6), the fertiliser inputs are now represented as a daily time series of mass inputs $\left(\mathrm{kg} \mathrm{N} \mathrm{ha}^{-1}\right.$ day $^{-1}$ ) read from a file. Thus, for the simulation period, it is possible to model multiple fertiliser applications within each year. Organic-N inputs, such as those from manure spreading or livestock, can be added as inputs to INCA. To incorporate organic-N inputs in this way, the application rate is specified in terms of an equivalent $\mathrm{N}$ mass $\left(\mathrm{kg} \mathrm{N} \mathrm{ha}^{-1} \mathrm{day}^{-1}\right)$ and, since the application rates for inorganic fertilisers are measured in terms of $\mathrm{kg} \mathrm{N} \mathrm{ha}^{-1}$ day ${ }^{-1}$ for both $\mathrm{NO}_{3}$ and $\mathrm{NH}_{4}$, the organic- $\mathrm{N}$ can be added directly to the inorganic-N contribution. Alternatively, the user can chose to assume that organic-N contributes directly to the unlimited organic$\mathrm{N}$ pool, and therefore no additional organic- $\mathrm{N}$ input is supplied as input. Multiple plant-growth periods can also be specified for the simulation period and, if available, effluent time series describing the effluent flow $\left(\mathrm{m}^{3} \mathrm{~s}^{-1}\right)$, and $\mathrm{NO}_{3}\left(\mathrm{mg} \mathrm{N} \mathrm{l}^{-1}\right)$ and $\mathrm{NH}_{4}\left(\mathrm{mg} \mathrm{N}^{-1}\right)$ concentrations entering each reach in the system (Appendix D, Table D.1). Thus, the model now has an interface designed to permit the inclusion of detailed time series data describing growing seasons, atmospheric deposition, fertiliser and STW effluent inputs if available. Alternatively, if such data are unavailable, single lumped values can be used to describe the fertiliser applications and effluent flows and concentrations. Also a single growth period can be specified. As such, the model can be applied to systems that are data rich or poor.

For the Kennet application, typical lumped, inorganic-N fertiliser application rates to arable and improved pasture grassland were obtained from the British Survey of Fertiliser Practice (Fertiliser Manufacturers' Association, 1994) and estimated as 108 and $125 \mathrm{~kg} \mathrm{~N} \mathrm{ha}^{-1} \mathrm{yr}^{-1}$, respectively. Based on local farming knowledge, it was assumed that fertiliser was applied evenly between mid-March and mid-August. The main plant-growing season was assumed to begin in early March and finish at the end of October, with the exception of arable land, where the growing season was assumed to end with the harvest in late August. Furthermore, it was assumed that any organic- $\mathrm{N}$ inputs from farmyard manure or wastes from grazing animals, contributed to the unlimited organic-N pool available for mineralisation.

\section{SPATIAL INPUT DATA}

To apply the model to a river catchment, the main channel is divided into reaches, typically based on the locations of flow or water chemistry sampling locations, or other points of interest. The land area draining into each reach is then calculated. In the case of the Kennet application, the 25 subcatchment boundaries were derived from the CEH's Digital Terrain Model, using a Geographical Information System (GIS) (Morris and Flavin, 1994). Further algorithms were developed to calculate the area of each sub-catchment and the percentage cover of each land-use type (Appendix D, Table D.2). In this application, the 18 land-use classes within the Institute of Terrestrial Ecology (ITE) Land Cover Map of Great Britain were aggregated into six land-use classes to limit the number of model parameters needed and linked with the six sets of land component equations used within INCA. The six land-use classes were forest, short vegetation (ungrazed), short vegetation (grazed, but not fertilised), short vegetation (fertilised), arable and urban. However, the definitions of the six land-use classes are not rigid, and may be changed for other INCA applications.

\section{MODEL CALIBRATION}

The model was calibrated in three stages. Firstly, the initial flows, soilwater, groundwater and streamwater $\mathrm{NO}_{3}$ and $\mathrm{NH}_{4}$ concentrations, and volumes in the plant/soil system and the in-stream component were set. The initial concentrations and volumes are listed in Tables D. 3 to D.5, and the values reflect the difference in the land management practices with arable and improved pasture having higher $\mathrm{NO}_{3}$ concentrations reflecting the historic fertiliser applications. As such, the initial flows and concentrations were related either to observation or some assumed knowledge about how the system behaves. For these reasons, the initial volumes and concentrations were set first. Given that the initial volumes relate to $1 \mathrm{~km}^{2}$ cell, then the average soil and groundwater depths were approximated as 3 (assuming a soil porosity of 0.45 ) and $60 \mathrm{~m}$, respectively.

All the hydrological parameters, relating to both the land and in-stream components, were then adjusted to obtain the best fit to the observed hydrographs available from the four gauging stations. In the calibration sequence, these parameters were then set because the hydrology controls the $\mathrm{N}$ mass stored and transferred, within both the land and in-stream components.

Finally, all the parameters controlling the $\mathrm{N}$ transformation 
Table 6. Nitrogen annual process and leaching loads: a comparison of literature and simulated values (adapted from Whitehead et al., 1998a).

\begin{tabular}{|c|c|c|}
\hline Land use/Process & 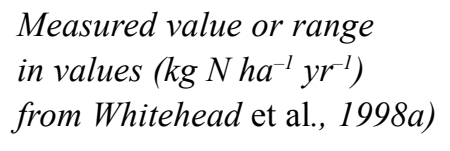 & $\begin{array}{l}\text { Simulated value for the } \\
\text { Kennet values } \\
\left(\mathrm{kgN} N \mathrm{~h}^{-1} y r^{-1}\right)\end{array}$ \\
\hline \multicolumn{3}{|l|}{ (1) $\mathrm{NO}_{3}$ uptake } \\
\hline Woodland & $17-153$ & 8 \\
\hline Unimproved grassland & $35-162$ & 5 \\
\hline Improved grassland & 105 & 103 \\
\hline Arable & 95 & 93 \\
\hline \multicolumn{3}{|l|}{ (2) Denitrification } \\
\hline Woodland & $<0.01-4$ & 2 \\
\hline Unimproved grassland & 1 & 1 \\
\hline Improved grassland & 19 & 14 \\
\hline Arable & & 17 \\
\hline \multicolumn{3}{|l|}{ (3) Nitrification } \\
\hline Woodland & $1-35$ & 29 \\
\hline Unimproved grassland & & 15 \\
\hline Improved grassland & & 109 \\
\hline Arable & & 40 \\
\hline \multicolumn{3}{|l|}{ (4) Mineralisation } \\
\hline Woodland & $10-292$ & 36 \\
\hline Unimproved grassland & 73 & 27 \\
\hline Improved grassland & $40-50$ & 53 \\
\hline Arable & 62 & 53 \\
\hline \multicolumn{3}{|l|}{ (5) Inorganic N leaching } \\
\hline Woodland & $<1-43$ & 2 \\
\hline Unimproved grassland & $1.8-5.3$ & 1 \\
\hline Improved grassland & & 17 \\
\hline Arable & $19-84$ & 30 \\
\hline
\end{tabular}

rates in the plant/soil system and in-stream were adjusted until the annual process loads were within the range reported in the literature (Table 6). It is a simplification of the model that all the land component processes are the same irrespective of location within the catchment. The in-stream nitrification and de-nitrification rates are spatially variable along the length of the main stem, and these were also adjusted until the model output matched, as closely as possible, the observed streamwater $\mathrm{NO}_{3}$ concentrations. To provide a quantitative estimate of the model goodness of fit a Co-efficient of Determination, defined by Nash and Sutcliffe (1970), was used to compare the model output of the old and new versions of INCA. The coefficient compared the simulated flows and streamwater $\mathrm{NO}_{3}$ concentrations produced by the two versions, with those observed at sites along the length of the River Kennet (Table 7).

\section{Results}

\section{SPATIAL VARIATIONS}

The simulation results relating to the original version of INCA are detailed in Whitehead et al., (2002). The new version of INCA conserved mass, with a balance achieved between input, output and storage. This was not the case for the original version. The mean flow and $\mathrm{NO}_{3}$ concentrations simulated by the new INCA version compare well with observations (Fig. 4). Some variation between the simulated and the observed mean $\mathrm{NO}_{3}$ concentration occurs since the mean of the simulated values is based on 365 values whereas the mean of the observations is based on between 12 and 47 values, depending on the data available. The Co-efficient of Determination was 0.8 , indicating good agreement between the simulated and observed mean concentrations, and an improvement on version 1.0 for which the co-efficient was 0.2 . The two mean $\mathrm{NO}_{3}$ concentrations observed at the end of the river were 
Table 7. A comparison of the simulated flows and $\mathrm{NO}_{3}$ concentrations generated by the original and new INCA versions fit with the 1998 observed data for reaches of the River Kennet. The comparison was made using the Co-efficient of Determination defined by Nash and Sutcliffe (1970).

\begin{tabular}{|c|c|c|c|c|c|c|}
\hline \multirow[t]{2}{*}{ Reach } & \multicolumn{3}{|c|}{ Flow - Co-efficient of Determination } & \multicolumn{3}{|c|}{ Nitrate - Co-efficient of Determination } \\
\hline & $\begin{array}{l}N^{o} \text { of } \\
\text { Observations }\end{array}$ & Version 1.0 & Version 1.6 & $\begin{array}{l}N^{o} \text { of } \\
\text { Observations }\end{array}$ & Version 1.0 & Version 1.6 \\
\hline 3 & & & & 13 & $<0.00$ & $<0.00$ \\
\hline 4 & & & & 47 & 0.10 & 0.08 \\
\hline 5 & 365 & 0.54 & 0.41 & 41 & 0.20 & 0.18 \\
\hline 6 & & & & 47 & 0.46 & 0.48 \\
\hline 7 & & & & 47 & 0.29 & 0.42 \\
\hline 8 & & & & 47 & 0.60 & 0.71 \\
\hline 9 & & & & 47 & 0.51 & 0.70 \\
\hline 10 & & & & 47 & 0.41 & 0.60 \\
\hline 11 & 365 & 0.76 & 0.74 & 46 & 0.60 & 0.80 \\
\hline 12 & & & & 3 & 0.20 & 0.24 \\
\hline 13 & & & & 14 & $<0.00$ & $<0.00$ \\
\hline 15 & 365 & 0.76 & 0.74 & & & \\
\hline 16 & & & & 12 & 0.41 & 0.52 \\
\hline 17 & & & & 12 & 0.53 & 0.43 \\
\hline 18 & & & & 12 & 0.54 & 0.66 \\
\hline 19 & & & & 12 & 0.43 & 0.62 \\
\hline 20 & & & & 13 & 0.53 & 0.54 \\
\hline 21 & 344 & 0.77 & 0.67 & & & \\
\hline 23 & & & & 11 & 0.34 & 0.67 \\
\hline 24 & & & & 11 & $<0.00$ & $<0.00$ \\
\hline 25 & & & & 10 & $<0.00$ & $<0.00$ \\
\hline
\end{tabular}

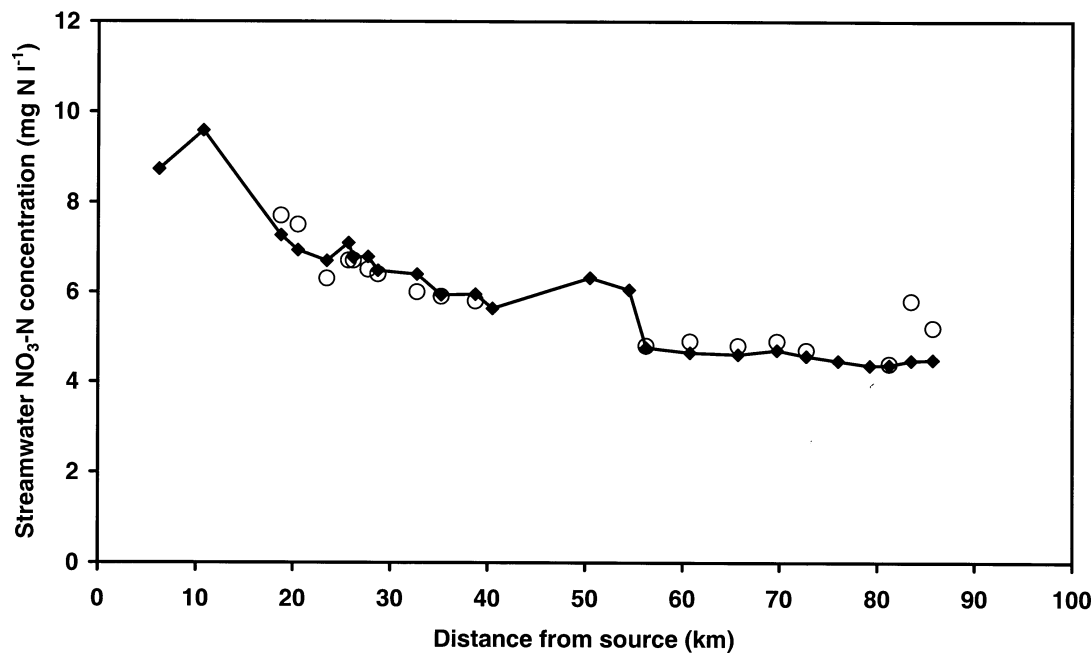

Fig. 4. Spatial variations in the simulated and the observed (a) flows and (b) $\mathrm{NO}_{3}$ concentrations along the main stem of the River Kennet. The simulated and observed data are marked with diamonds and open circles, respectively.

higher than predicted. Both observations relate to reaches draining from urban areas in Reading; therefore, it is possible that the predicted streamwater $\mathrm{NO}_{3}$ concentrations are too low because some STW discharges are unaccounted for.
As expected, the simulated and observed flows accumulate along the main stem, whilst the simulated and observed $\mathrm{NO}_{3}$ concentrations decrease from a maximum of approximately $9 \mathrm{mg} \mathrm{N}^{-1}$, in reach 2 to $4 \mathrm{mg} \mathrm{N}^{-1}$ in reach 25 . This decrease 
indicates the transition from intensive arable farming in the upper reaches to areas of relatively more grazing, woodland and urbanisation found in the lower reaches of the Kennet. The decrease also suggests that the point source inputs from STW at Newbury, Woolhampton and Padworth had no major impact on the mean $\mathrm{NO}_{3}$ concentrations.

\section{TEMPORAL VARIATIONS}

The fit of the simulated flow output to that observed was good at the gauging stations in the lower reaches of the catchment. In the upper reaches, the simulated flows tended to be overestimates when compared with the observed flows, though the dynamics were reasonable (Fig. 5; Table 6). In the upper Kennet, it is known that the topological catchment area is greater than the hydrological catchment area (NERC, 1998). It is the topological catchment area that is used within INCA to generate the flow estimates, and therefore this seems a likely explanation for the over-estimation.

The observed streamwater $\mathrm{NO}_{3}$ concentrations at Marlborough vary between 6 and $9 \mathrm{mg} \mathrm{N}^{-1}$ and between 3.5 and $5.5 \mathrm{mg} \mathrm{N}^{-1}$ at Fobney. Such variation is due to the

(a) Knighton

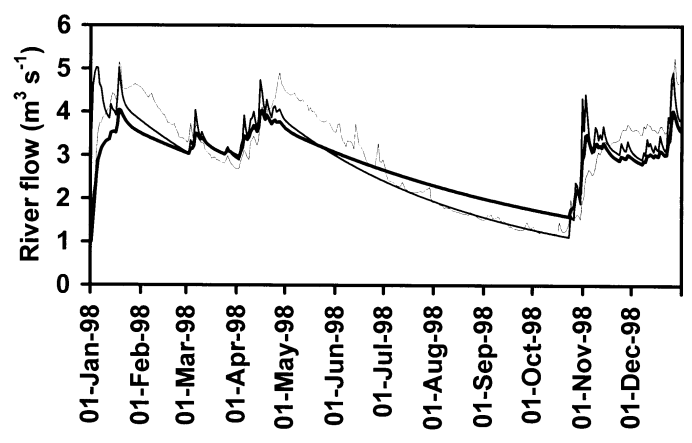

(b) Theale

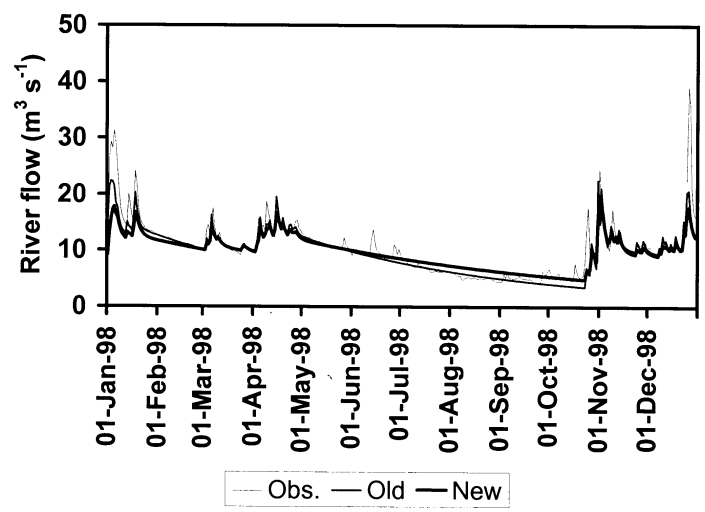

complex interaction of processes, which govern the $\mathrm{NO}_{3}$ formation and removal both in the plant/soil system and instream. From November to March, streamwater concentrations of $\mathrm{NO}_{3}$ at both sites are higher than during the rest of the year. This implies the flushing of $\mathrm{NO}_{3}$ from the soils by precipitation during the winter and early spring period. During summer, $\mathrm{NO}_{3}$ is removed from both the plant/ soil and stream systems through biological uptake and consequently the observed and simulated concentrations decline. This decline is also probably linked to lower precipitation inputs during the summer months and reduced mineralisation, which is impaired by dry soil conditions.

The model simulations suggest that the soil $\mathrm{NO}_{3}$ concentrations vary from around $10.5 \mathrm{mg} \mathrm{N}^{-1}$ in winter to $7 \mathrm{mg} \mathrm{N}^{-1}$ in summer, whilst the groundwater concentrations stay constant at around $10 \mathrm{mg} \mathrm{N}^{-1}$ all year. No observed soil water concentration data are available, but groundwater samples taken from boreholes in the upper reaches of the Kennet catchment around Axford and analysed by the CEH indicate concentrations of around 4 to $6 \mathrm{mg} \mathrm{N}^{-1}$. This suggests that the groundwater-volume estimate used in the model calibration of $6^{*} 10^{7} \mathrm{~m}^{3}$ per $\mathrm{km}^{2}$ (equivalent to a water depth of $60 \mathrm{~m}$ ) may be too small, or the initial groundwater

(a) Knighton

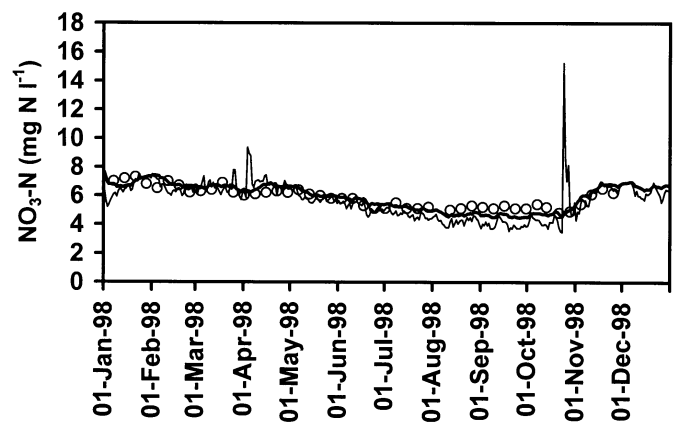

(b) Padworth

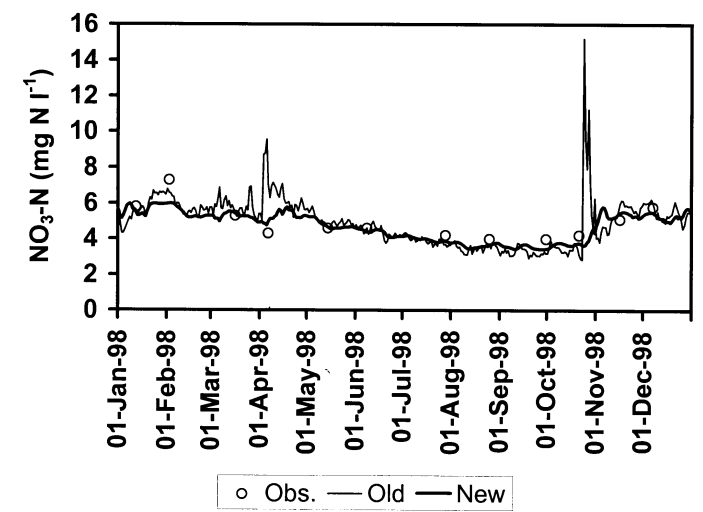

Fig. 5. A comparison of the model predictions using the old (v1.0) and the new (v1.6) versions of INCA, and the observed (a) flow and (b) streamwater $\mathrm{NO}_{3}$ concentrations at sites in the upper and lower reaches of the River Kennet at Knighton and Theale (flow) and Padworth (concentration data), respectively. 
$\mathrm{NO}_{3}$ concentration too high. Further research is required as to whether the volume or concentration or both should be adjusted.

\section{SPATIAL AND TEMPORAL DISTRIBUTION OF $\mathrm{NO}_{3}$ LOADS}

The INCA simulations indicate that arable land provides at least $80 \%$ of the $\mathrm{NO}_{3}$ load along the main stem of the river and that this input is broadly constant throughout the year, probably due to the application of fertiliser top dressing throughout crop growth (Fig. 6). The annual leaching load from arable land is $30 \mathrm{~kg} \mathrm{ha}^{-1} \mathrm{year}^{-1}$, which is greater than that from fertilised grassland $\left(17 \mathrm{~kg} \mathrm{ha}^{-1}\right.$ year $\left.{ }^{-1}\right)$ or woodland areas $\left(1.4 \mathrm{~kg} \mathrm{ha}^{-1}\right.$ year $\left.^{-1}\right)$. The contribution from point sources, which are mainly STWs, is greater in the upper reaches of the system where the effluent concentrations are higher and the lower flows in the river provide less dilution (Fig. 7). The inputs from STW are more important during the summer months of August and September when the flows are usually lowest. Upstream of site 7, there is only one important market town (Marlborough), but near the source areas, small (e.g. septic tank) inputs may be important in relation to nutrient concentration owing to the lack of dilution. The input of septic tanks was not modelled explicitly, though their impact may be factored into the

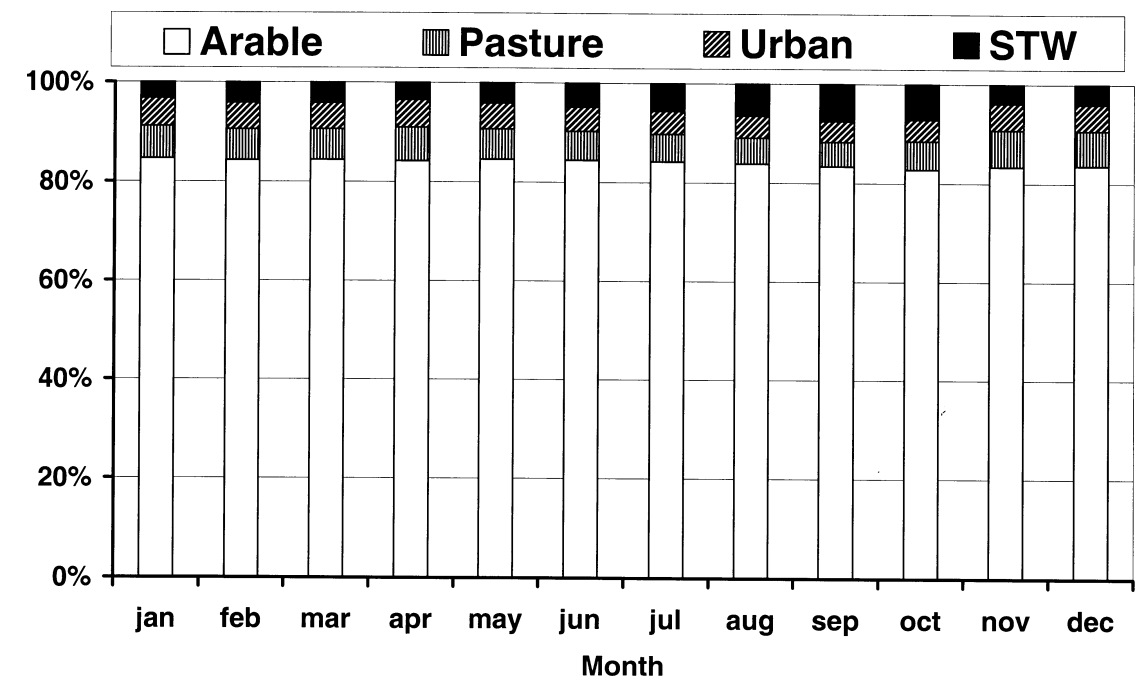

Fig. 6. The relative $\mathrm{NO}_{3}$ load leached each month from the individual landscape types in the Kennet river system. The estimates of the monthly loads are derived from the INCA simulations for 1998.

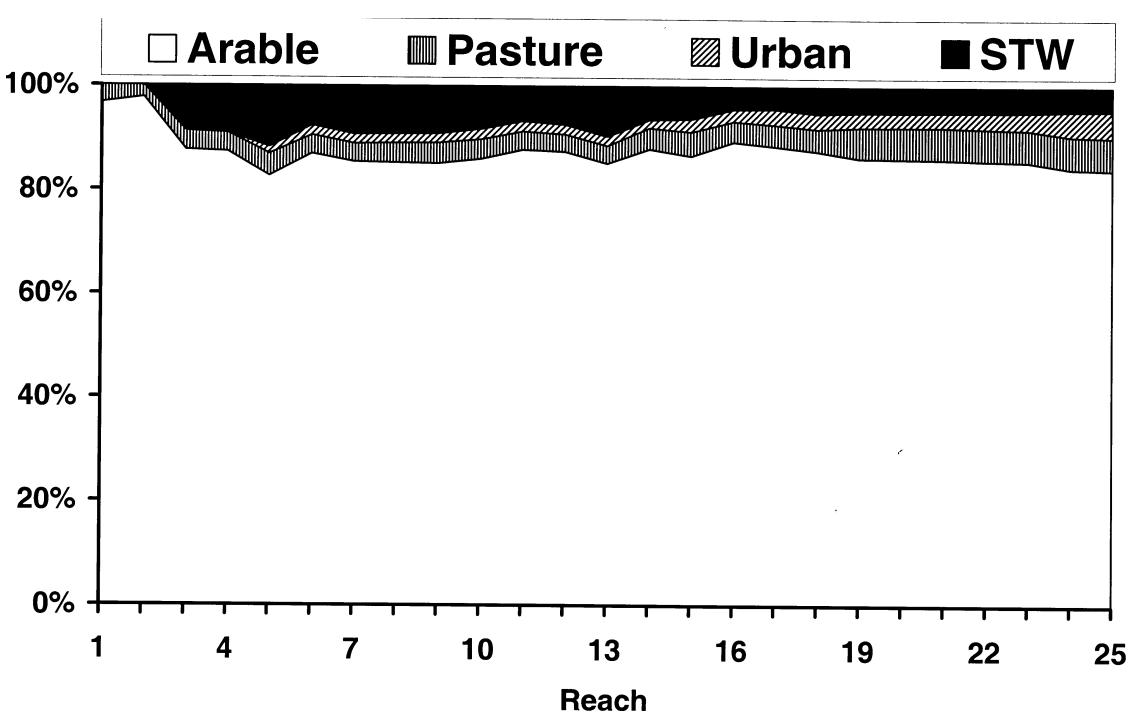

Fig. 7. The relative contribution from each land use type to the $\mathrm{NO}_{3}$ load entering the River Kennet in each reach. 
simulation of $\mathrm{N}$ transported via diffuse flow paths from each land use. The relative importance of pasture and urban sources increases downstream, as more land is used for grazing and the towns become larger.

The prediction of the annual loads associated with the $\mathrm{N}$ processes occurring in the plant/soil system are all in the range reported within the literature; however, due to the uncertainty in the interpretation of the model parameters which determine the process loads, the estimates of the absolute load values remain tentative (Table 6). Arable land and fertilised grassland receive the largest $\mathrm{NO}_{3}$ load because of fertiliser inputs. Consequently, arable land exhibited the largest leaching of $\mathrm{NO}_{3}$. The largest plant uptake occurred for fertilised grassland probably because after crop harvest it was assumed that plant uptake ceased whilst grassland used for hay and silage would continue to grow for the total duration of the growing season. For all land-use types, the modelled processes involving the largest transfers of $\mathrm{N}$ were $\mathrm{NO}_{3}$ uptake, organic matter mineralisation and $\mathrm{NH}_{4}$ nitrification. Simulated nitrification is greater than mineralisation under fertilised grassland, due probably to the addition of $\mathrm{NH}_{4}$ as fertiliser. Under arable, woodland and ungrazed, unfertilised grassland, modelled mineralisation is greater than nitrification as the simulated $\mathrm{NH}_{4}$ is derived mainly from organic $\mathrm{N}$ in these cases.

\section{Discussion}

The simulation results indicate the new version (v1.6) of INCA improves on the original (v1.0). Specifically, the results show that:

- The new version conserves water volume and $\mathrm{N}$ mass, in both the land and in-stream components, whilst the original model did not. As in the original model, the equations in the new version are dimensionally correct and the process rates described by the equations remain a function of $\mathrm{N}$ concentration. Given this, the new model equations offer an improvement on the original version.

- The new version of INCA generates simulated streamwater $\mathrm{NO}_{3}$ concentrations that match the observed data more closely when compared to those simulated by the original version.

The ability of the new version to reproduce the annual mean streamwater $\mathrm{N}$ concentrations and general seasonal patterns suggests that the key factors and processes controlling the $\mathrm{N}$ behaviour are included within the new version of the INCA model, and the mathematical representation of the $\mathrm{N}$ processes is reasonable as a first approximation. However, given the dominance of arable agriculture in the Kennet catchment, then the system may not be sufficiently dynamic with respect to $\mathrm{N}$ to allow complete testing of the internal process representations used in the model. In addition, further research to compare the versions more rigorously should involve split-sample applications of both the old and new versions of the model to the Kennet system, whereby the two versions are calibrated and tested using data collected over two periods, ideally with each period being a minimum of two years. Other applications of the new version of the INCA model, reported within this volume, suggest that the model is capable of simulating mixed agricultural and forested systems and that the model performs well when calibrated for one period and tested using data collected over a second period (Jarvie et al., 2002b; Langusch and Matzner, 2002). Both versions of the model produced simulated annual $\mathrm{N}$ loads associated with the plant/soil system within the ranges recorded in the literature, however the inclusion of storage volumes makes the new version conceptually more appealing, especially when simulating long timescales (> 1year; e.g. Jarvie et al., 2002b).

Though the equation changes and the addition of the storage volumes in the new version appear beneficial, at present definite improvements in the INCA structure cannot be verified rigorously due to the problems of:

- identifying a unique set of parameter values which generate the optimum model fit to the observed data, known as parameter uncertainty (Oreskes et al., 1994);

- the uncertainty in the model representation of the complex $\mathrm{N}$ dynamics, known as structural uncertainty (Beven, 1993; Neal, 1997);

- the observed data uncertainty, in particular the lack of exhaustivity in observations (Durand et al., 2002).

Parameter uncertainty arises mainly due to the difficulties in interpreting the physical meaning of the parameters and the difficulty of making direct measurements at the appropriate scale, whilst structural uncertainty arises since models are necessarily a simplification of reality. Despite these problems, INCA provides a significant learning tool since it represents the consensus of 20 scientists, with backgrounds in both laboratory and field-based process studies and modelling. Moreover, the same group of scientists has tested the model in diverse systems throughout Europe and recommended revisions regarding which processes and factors should be included to simulate complex and diverse systems ranging in spatial scale from plots to large $\left(c .4000 \mathrm{~km}^{2}\right)$ river systems. Thus, INCA has provided a formal basis for integrating concepts of river system functioning. 
The application of the model to the Kennet system and elsewhere has highlighted the need to collect and interpret long-term water chemistry and ecological datasets. In many cases, ecological monitoring is not undertaken routinely alongside hydrochemical studies but, since the aim of many water quality programmes is to assess ultimately the ecological affects of water quality changes, then ecological data are of the utmost importance. Such data sets are needed to describe the changes in response to land management and climatic changes that may occur over several decades. Without such data, it will be impossible to verify the accuracy of model results so that catchment managers, policy-makers and economists will be unable to make sound decisions based on model output.

To aid the solution of the problems of parameter and structural uncertainty it is recommended that further work, beyond the scope of this study, be done. Monte Carlo techniques when coupled with General Sensitivity Analysis (GSA) could provide some indication of the relative importance of different parameters within the model when tested against pre-defined behaviour criteria, and can therefore be used as an aid in assessing parameter uncertainty (Hornberger and Spear, 1980; Spear and Hornberger, 1980). A sensitivity analysis of the INCA model parameters would highlight parameters redundant in a particular application and strong interactions between parameters governing opposite processes, such as nitrification and denitrification. Since parameters redundant in one application may not be so in another, it is necessary to collate the sensitivity analysis results from many applications to identify those parameters most important in controlling the model behaviour and those that are redundant. With these results, the model structure could be changed to remove the redundant components or recommendations could be made to a user to set such parameters to zero and concentrate on those remaining. An opportunity to do this would arise by applying GSA to all the model applications done as part of the INCA project, where the model as applied to river systems and plots throughout Europe (Wade et al., 2002). In addition, the Generalised Likelihood Uncertainty Estimation (GLUE) could be used to assess the uncertainty of model predictions using a Bayesian approach (Franks and Beven, 1997). Future work could also involve a detailed comparison of the old and new versions of the model using GSA, when both are applied using a split-sample test. The results would be used to investigate further differences in behaviour and what these imply for catchment and in-stream processes.

To address the issue of structural uncertainty, the output from INCA should be compared with other models, such as TNT (Beaujouan et al., 2001). If the models produce significantly different simulation results or predictions of future changes, then a review of the structure of each may lead to insights into the key factors controlling the output response and, therefore, which factors are most important in the real river system. New approaches based on the construction of modelling hierarchies such as Functional Unit Networks or the coupling of Fractal and Fourier Analysis to analyse catchment water quality signals may provide suitable alternative model structures with which to compare process based models such as INCA (Langan et al., 1997; Neal, 1997; Wade et al. 2001; Kirchner et al., 2001). Such analysis coupled with massively parallel computers permitting the faster solution of highly non-linear equations or more accurate and higher resolution remotely sensed data allowing a better definition of model inputs, could lead to model structures more representative of reality. However, as it is impossible to measure every factor or process within an environmental system, the ability to simulate and predict a catchment's behaviour exactly in response to environmental perturbations remains unlikely and, therefore, data interpretation remains the most important method for assessing the likely response of streamwater concentrations to environmental perturbations. Despite this, INCA provides a useful aid to understanding $\mathrm{N}$ dynamics in systems ranging from plot studies to large catchments under environmental change scenarios. If the model is used within a pragmatic framework, to infer the likely first order changes in response to environmental perturbations, and process knowledge is used to infer the likely second order effects, then it will be a useful tool for economists, catchment managers and policy makers.

\section{Conclusions}

The new version of the INCA model represents a significant advance in the modelling of streamwater $\mathrm{NO}_{3}$ concentrations as the model was based on the consensus of field scientists and modellers working in diverse environments spanning Europe. The recent developments have added new features including retention volumes and rigorous mass-balance checks whilst the new version retains the key features of the original model to ensure a pragmatic balance between useful model output, structural complexity and required input data. Moreover, the model can be applied over a wide range of spatial and temporal scales. Initial model testing, using data collected in the Kennet system, indicates that the model can simulate the annual and seasonal variations in the streamwater $\mathrm{NO}_{3}$ concentrations, though limitations imposed by parameter and structural uncertainty mean that any inferences regarding river system functioning must remain tentative until confirmed by experimental data. 


\section{Acknowledgements}

This research is supported by the European Commission (Project EVK1-1999-00011), and the results are derived from collaborations between all the project partners, who are listed on the project website: http://www.reading.ac.uk/ INCA. The authors would like to thank Heather Browning for help with the diagrams.

\section{References}

Alexander, M., 1961, Introduction to Soil Microbiology, Wiley, Chichester, UK.

Beaujouan, V., Durand, P. and Ruiz, L., 2001. Modelling the effect of the spatial distribution of agricultural practices on nitrogen fluxes in rural catchments. Ecol. Model., 137, 91-103.

Beven, K. J., 1993. Prophecy, reality and uncertainty in distributed hydrological modelling. Adv. Water Resour., 16, 41-51.

Bowden, W.B., 1987, The biogeochemistry of nitrogen in freshwater wetlands. Biogeochemistry, 4, 313-348.

Chapra, S .C., 1997. Surface Water-Quality Modelling, McGrawHill, New York, 560-576.

Durand, P., Gascuel-Odoux, C and Cordier, M., 2002. Parameterisation of hydrological models: a review and lessons learned form studies of an agricultural catchment (Naizin, France). Agronomy, In press.

Fertiliser Manufacturers' Association, 1994. British Survey of Fertiliser Practice: Fertiliser use on Farm Crops. HMSO. P. O. Box 276, London. SW9 5DT.

Franks, S. W. and Beven, K. J., 1997. Bayesian estimation of uncertainty in land surface-atmosphere flux predictions. $J$. Geophys. Res., 102, 23991-23999.

Green, F.H. and Harding, R.J., 1979. Altitudinal gradients of soil temperature in Europe. Inst. Br. Geographers, 5, 248-315.

Groffman, P.M., Hanson, G.C., Kiviat, E. and Stevens, G., 1996. Variation in microbial biomass and activity in four different wetland types. Soil Sci. Soc. America J., 60, 622-629.

Gustard, A., Marhsall, D. C. W. and Sutcliffe, M. F., 1987. Low flow estimation in Scotland. Institute of Hydrology Report 101, Institute of Hydrology, Wallingford, UK.

Hall, R.L. and Harding, R.J., 1993. The Water Use of the Balquhidder Catchments: A Process Approach, J. Hydrol., 145, 285-315.

Hornberger, G. M. and Spear, R. C., 1980. Eutrophication in Peel Inlet - I. The problem-defining behaviour and a mathematical model for the phosphorus scenario. Water Res., 14, 29-42.

Hough, M., Palmer, S., Weir, A., Lee, M. and Barrie, I., 1997. The Meteorological Office Rainfall and Evaporation Calculation System: MORECS Version 2.0 (1995). An update to Hydrological Memorandum 45. Meteorological Office, Bracknell, pp.80.

Jarvie, H.P., Neal, C., Williams, R.J., Tagg, A., Neal, M., Wickham, H.D., Hill, L.K., Wade, A.J., Warwick, A. and White, J., 2002a. Phosphorus sources, speciation and dynamics in a lowland eutrophic Chalk river: the River Kennet, UK. Sci. Total Environ., 282/283, 175-203.

Jarvie, H.P., Wade, A.J., Butterfield, D., Virtue, W. A., Dryburgh, W., Tindall, I. and McCraw, A., 2002b. Modelling the nitrogen dynamics and distributions in the River Tweed, Scotland: an application of the INCA model. Hydrol. Earth Syst. Sci., 6, 433453.

Kirchner, J. W., Feng, X. and Neal, C., 2002. Fractal stream chemistry and its implications for contaminant transport in catchments, Nature, 403, 524-527.
Langan, S. J., Wade, A. J., Smart, R., Edwards, A. C., Soulsby, C., Billett, M. F., Jarvie, H. P., Cresser, M. S., Owen, R. and Ferrier, R. C., 1997. The prediction and management of water quality in a relatively unpolluted major Scottish catchment: current issues and experimental approaches. Sci. Total Environ., 194/195, 419-435.

Langusch, J. and Matzner, E., 2002. N fluxes in two nitrogen saturated forested watersheds in Germany: Dynamics and modelling with INCA. Hydrol. Earth Syst. Sci., 6, 383-394.

Morris, D. G. and Flavin, R. W., 1994. Sub-set of the UK $50 \mathrm{~m}$ by $50 \mathrm{~m}$ hydrological digital terrain model grids. NERC. Institute of Hydrology, Wallingford.

Nash, J. E. and Sutcliffe, J. V., 1970. River flow forecasting through conceptual models Part 1, A discussion of principles. J. Hydrol., 10, 282-290.

Neal, C., 1997. A view of water quality from the Plynlimon watershed. Hydrol. Earth Syst. Sci., 1: 743-753.

Neal, C., Jarvie, H. P., Wade, A. J. and Whitehead, P. G., 2002. Water quality functioning of lowland permeable catchments: inferences from an intensive study of the River Kennet and upper River Thames. Sci. Total Environ., 282/283, 471-490.

Natural Environment Research Council (NERC) 1998. Hydrological Data United Kingdom - Hydrometric Register and Statistics 1991-1995, T. J. Marsh and M. L. Lees (Eds.), Institute of Hydrology, Wallingford, UK. pp. 207.

Oreskes, N., Shrade-Frechette, K. and Belitz, K., 1994. Verification, Validation and Confirmation of Numerical Models in the Earth Sciences. Science, 263, 641-646.

Rodgers, I. R., 1993. Transport and deposition models needs for power generation. In: Pollutant Transport and Deposition Modelling, Report on the Conclusions of the National Forum, ICON.

RGAR., 1997. Acid Deposition in the United Kingdom 1992-1994. Fourth Report of the Review Group on Acid Rain. Department of the Environment, London, pp 176.

Spear, R. and Hornberger, G. M., 1980. Eutrophication in Peel Inlet - II. Identification of critical uncertainties via Generalized Sensitivity Analysis. Water Res., 14, 43-49.

Wade, A. J., Neal, C., Soulsby, C., Langan, S. J and Smart, R. P., 2001 On modelling the effects of afforestation on acidification in heterogeneous catchments at different spatial and temporal scales. J. Hydrol., 250, 149-169.

Wade, A. J., Whitehead, P. G. and O'Shea, L. C. M., 2002. The prediction and management of aquatic nitrogen pollution across Europe: An introduction to the Integrated Nitrogen in European Catchments project (INCA). Hydrol. Earth Syst. Sci., 6, 299313.

Whitehead, P. G., Wilson, E. J. and Butterfield, D., 1998a. A semidistributed Nitrogen Model for Multiple Source Assessments in Catchments (INCA): Part 1 - Model Structure and Process Equations. Sci. Total Environ., 210/211, 547-558.

Whitehead, P. G., Wilson, E. J., Butterfield, D. and Seed, K., 1998b. A semi-Distributed Integrated Flow and Nitrogen Model for Multiple Source Assessment in Catchments (INCA): Part II Application to large River Basins in South Wales and Eastern England. Sci. Total Environ., 210/211, 559-583.

Whitehead, P.G., Johnes, P. J. and D. Butterfield., 2002. Steady State and dynamic modelling of nitrogen in the River Kennet: Impacts of land use change since the 1930s. Sci. Total Environ., 282/283, 417-434.

Wright, J. F., 2002. A comparison of the macrophyte cover and macroinvertebrate fauna at three sites on the R. Kennet in the mid 1970s and late 1990s. . Sci. Total Environ., 282/283, 121142. 


\section{Appendix A}

\section{LAND COMPONENT: EQUATIONS TO TRACK THE}

WATER VOLUME AND N MASS BALANCE.

Change in $\mathrm{NO}_{3}$ mass input into system, $x_{7}\left(\mathrm{~kg} \mathrm{~N} \mathrm{~km}^{-2}\right)$

$$
\frac{d x_{7}}{d t}=U_{2} .100
$$

Change in $\mathrm{NO}_{3}$ mass output from system, $x_{8}\left(\mathrm{~kg} \mathrm{~N} \mathrm{~km}^{-2}\right)$

$$
\frac{d x_{8}}{d t}=\frac{(1-\beta) x_{1} x_{3} .86400}{V_{r}+x_{11}}+\frac{x_{2} x_{4} \cdot 86400}{x_{12}}
$$

Change in $\mathrm{NH}_{4}$ mass input into system, $x_{9}\left(\mathrm{~kg} \mathrm{~N} \mathrm{~km}^{-2}\right)$

$$
\frac{d x_{9}}{d t}=U_{4} .100
$$

Change in $\mathrm{NH}_{4}$ mass output from system, $x_{10}\left(\mathrm{~kg} \mathrm{~N} \mathrm{~km}^{-2}\right)$

$$
\frac{d x_{10}}{d t}=\frac{(1-\beta) x_{1} x_{5} .86400}{V_{r}+x_{11}}+\frac{x_{2} x_{6} \cdot 86400}{x_{12}}
$$

Change in soil water drainage volume, $x_{11}\left(\mathrm{~m}^{3} \mathrm{~km}^{-2}\right)$

$$
\frac{d x_{11}}{d t}=\left(U_{1}-x_{1}\right) .86400
$$

Change in groundwater drainage water volume, $x_{12}$ $\left(\mathrm{m}^{3} \mathrm{~km}^{-2}\right)$

$$
\frac{d x_{12}}{d t}=\left(\beta . x_{1}-x_{2}\right) .86400
$$

Change in water flow input, $x_{13}\left(\mathrm{~m}^{3} \mathrm{~km}^{-2}\right)$

$$
\frac{d x_{13}}{d t}=U_{1} .86400
$$

Change in water flow output, $x_{14}\left(\mathrm{~m}^{3} \mathrm{~km}^{-2}\right)$

$$
\frac{d x_{14}}{d t}=\left((1-\beta) \cdot x_{1}+x_{2}\right) \cdot 86400
$$

Accumulated $\mathrm{N}$ mass associated with plant $\mathrm{NO}_{3}$ uptake, $x_{15}$ $\left(\mathrm{kg} \mathrm{N} \mathrm{km}^{-2}\right)$, is calculated from integrating the change in plant $\mathrm{NO}_{3}$ uptake, $d x_{15} / d t$

$$
\frac{d x_{15}}{d t}=C_{3} S_{1} S_{2} \frac{x_{3}}{V_{r}+x_{11}} 10^{6}
$$

Accumulated $\mathrm{N}$ mass associated with denitrification, $x_{16}(\mathrm{~kg}$ $\mathrm{N} \mathrm{km}^{-2}$ ), is calculated from integrating the change in denitrification, $d x_{16} / d t$

$$
\frac{d x_{16}}{d t}=C_{1} S_{1} \frac{x_{3}}{V_{r}+x_{11}} 10^{6}
$$

Accumulated $\mathrm{N}$ mass associated with nitrification, $x_{17}(\mathrm{~kg}$ $\mathrm{N} \mathrm{km}^{-2}$ ), is calculated from integrating the change in nitrification, $d x_{1 f} d t$

$$
\frac{d x_{17}}{d t}=C_{4} S_{1} \frac{x_{5}}{V_{r}+x_{11}} 10^{6}
$$

Accumulated $\mathrm{N}$ mass associated with fixation, $x_{18}(\mathrm{~kg} \mathrm{~N}$ $\mathrm{km}^{-2}$ ), is calculated from integrating the change in fixation, $d x_{18} d t$

$$
\frac{d x_{18}}{d t}=C_{2} \cdot 100
$$

Accumulated $\mathrm{N}$ mass associated with plant $\mathrm{NH}_{4}$ uptake, $x_{19}$ $\left(\mathrm{kg} \mathrm{N} \mathrm{km}^{-2}\right)$, is calculated from integrating the change in the plant $\mathrm{NH}_{4}$ uptake, $d x_{19} / d t$

$$
\frac{d x_{19}}{d t}=C_{7} S_{1} S_{2} \frac{x_{5}}{V_{r}+x_{11}} 10^{6}
$$

Accumulated $\mathrm{N}$ mass associated with immobilisation, $x_{20}$ $\left(\mathrm{kg} \mathrm{N} \mathrm{km}^{-2}\right)$, is calculated from integrating the change in immobilisation, $d x_{20} / d t$

$$
\frac{d x_{20}}{d t}=C_{6} S_{1} \frac{x_{5}}{V_{r}+x_{11}} 10^{6}
$$

Accumulated $\mathrm{N}$ mass associated with mineralisation, $x_{21}(\mathrm{~kg}$ $\mathrm{N} \mathrm{km}^{-2}$ ), is calculated from integrating the change in mineralisation, $d x_{21} / d t$

$$
\frac{d x_{21}}{d t}=C_{5} S_{1} .100
$$

The water and $\mathrm{N}$ mass-balances within the land component are calculated and the results are displayed on the load charts in INCAv1.6.

The $\mathrm{N}$ input to each land use in each reach is calculated as:

$$
\text { Input }=x_{7}+x_{9}+x_{18}+x_{21}
$$

where $x_{7}$ depends on the daily $\mathrm{NO}_{3}$ fertiliser and deposition inputs, $\left(\mathrm{kg} \mathrm{N} \mathrm{km}^{-2}\right), x_{9}$ depends on the daily $\mathrm{NH}_{4}$ fertiliser and deposition inputs, $\left(\mathrm{kg} \mathrm{N} \mathrm{km}^{-2}\right), x_{18}$ is the daily fixation mass $\left(\mathrm{kg} \mathrm{N} \mathrm{km}^{-2}\right)$, and $x_{21}$ is the daily mineralisation mass $\left(\mathrm{kg} \mathrm{N} \mathrm{km}^{-2}\right)$.

The output from each land use in each reach is calculated as:

$$
\text { Output }=x_{8}+x_{10}+x_{16}+x_{15}+x_{19}
$$

where 
$x_{8}=$ accumulated $\mathrm{NO}_{3}$ leached $\left(\mathrm{kg} \mathrm{N} \mathrm{km}^{-2}\right)$;

$x_{10}=$ accumulated $\mathrm{NH}_{4}$ leached $\left(\mathrm{kg} \mathrm{N} \mathrm{km}^{-2}\right)$;

$x_{15}=$ accumulated $\mathrm{NO}_{3}$ loss through denitrification $(\mathrm{kg} \mathrm{N}$ $\left.\mathrm{km}^{-2}\right)$;

$x_{16}=$ accumulated $\mathrm{NO}_{3}$ loss through plant uptake $(\mathrm{kg} \mathrm{N}$ $\left.\mathrm{km}^{-2}\right)$;

$x_{19}=$ accumulated $\mathrm{NH}_{4}$ through immobilisation $(\mathrm{kg} \mathrm{N}$ $\left.\mathrm{km}^{-2}\right)$.

The $\mathrm{N}$ stored in each land use in each reach is calculated as:

$$
\text { Storage }=x_{3}+x_{4}+x_{5}+x_{6}
$$

where

$x_{3}=\mathrm{NO}_{3}$ stored in soil $\left(\mathrm{kg} \mathrm{N} \mathrm{km}^{-2}\right)$;

$x_{4}=\mathrm{NO}_{3}$ stored in groundwater $\left(\mathrm{kg} \mathrm{N} \mathrm{km}^{-2}\right)$;

$x_{5}=\mathrm{NH}_{4}$ stored in soil $\left(\mathrm{kg} \mathrm{N} \mathrm{km}^{-2}\right)$;

$x_{6}=\mathrm{NH}_{4}$ stored in groundwater $\left(\mathrm{kg} \mathrm{N} \mathrm{km}^{-2}\right)$.

The initial $\mathrm{N}$ mass stored in each land use in each reach is calculated as:

$$
\text { Initial }=x_{3,0}+x_{4,0}+x_{5,0}+x_{6,0}
$$

where

$x_{3,0}=\mathrm{NO}_{3}$ stored in soil at time, $t=0\left(\mathrm{~kg} \mathrm{~N} \mathrm{~km}^{-2}\right)$;

$x_{4,0}=\mathrm{NO}_{3}$ stored in groundwater, $t=0\left(\mathrm{~kg} \mathrm{~N} \mathrm{~km}^{-2}\right)$;

$x_{5,0}=\mathrm{NH}_{4}$ stored in soil, $t=0\left(\mathrm{~kg} \mathrm{~N} \mathrm{~km}^{-2}\right)$;

$x_{6,0}=\mathrm{NH}_{4}$ stored in groundwater, $t=0\left(\mathrm{~kg} \mathrm{~N} \mathrm{~km}^{-2}\right)$.

The user supplies all the initial values as input.

The $\mathrm{N}$ mass-balance for each land use in each reach is calculated as:

$$
\text { Bal }=\text { Initial }+ \text { Input }- \text { Output }- \text { Storage }
$$

Thus, if $\mathrm{N}$ mass-balance is achieved then the balance will equal zero.

The water balance was expressed as

$B a l_{w}=\left(x_{11,0}+x_{12,0}+V_{r}\right)+x_{13}-x_{14}-\left(x_{11}+x_{12}\right)(\mathrm{A} .21)$

where $x_{11,0}$ and $x_{12,0}$ are the initial soil drainage water and groundwater volumes, and all the other terms are as previously defined.

\section{Appendix B}

\section{INSTREAM COMPONENT: EQUATIONS TO TRACK}

THE WATER VOLUME AND N MASS BALANCE

Change in $\mathrm{NO}_{3}$ mass input into reach, $x_{25}(\mathrm{~kg} \mathrm{~N})$

$$
\frac{d x_{25}}{d t}=S_{5}
$$

Change in $\mathrm{NH}_{4}$ mass input into reach, $x_{26}(\mathrm{~kg} \mathrm{~N})$

$$
\frac{d x_{26}}{d t}=S_{6}
$$

Change in $\mathrm{NO}_{3}$ mass output from reach, $x_{27}(\mathrm{~kg} \mathrm{~N})$

$$
\frac{d x_{27}}{d t}=\frac{x_{22} x_{23} \cdot 86400}{x_{29}}
$$

Change in $\mathrm{NH}_{4}$ mass output from reach, $x_{28}(\mathrm{~kg} \mathrm{~N})$

$$
\frac{d x_{28}}{d t}=\frac{x_{22} x_{24} .86400}{x_{29}}
$$

Change in reach volume, $x_{29}\left(\mathrm{~m}^{3}\right)$

$$
\frac{d x_{29}}{d t}=\left(S_{4}-x_{22}\right) \cdot 86400
$$

Change in water flow input to reach, $x_{30}\left(\mathrm{~m}^{3}\right)$

$$
\frac{d x_{30}}{d t}=S_{4} .86400
$$

Change in water flow output to reach, $x_{31}\left(\mathrm{~m}^{3}\right)$

$$
\frac{d x_{31}}{d t}=x_{22} .86400
$$

Accumulated $\mathrm{N}$ mass associated with denitrification, $x_{32}(\mathrm{~kg}$ $\mathrm{N}$ ), is calculated from integrating the change in denitrification, $d x_{32} / d t$

$$
\frac{d x_{32}}{d t}=\frac{C_{11} a_{5, t-1} x_{29}}{1000}
$$

Accumulated $\mathrm{N}$ mass associated with nitrification, $x_{33}(\mathrm{~kg}$ $\mathrm{N}$ ), is calculated from integrating the change in nitrification, $d x_{33} / d t$

$$
\frac{d x_{33}}{d t}=\frac{C_{10} a_{6, t-1} x_{29}}{1000}
$$

The $\mathrm{N}$ mass-balance within the in-stream component is calculated and the results are displayed on the load charts in INCAv1.6. The input to each reach is calculated as:

$$
\text { Input }=x_{25}+x_{26}
$$

The output from each land use in each reach is calculated 
as:

$$
\text { Output }=x_{27}+x_{28}+x_{29}
$$

The $\mathrm{N}$ stored in each land use in each reach is calculated as:

$$
\text { Storage }=x_{29}
$$

where the terms are as defined previously.

The initial $\mathrm{N}$ mass stored in each land use in each reach is calculated as:

$$
\text { Initial }=x_{3,0}+x_{4,0}+x_{5,0}+x_{6,0}
$$

where

$x_{3,0}=\mathrm{NO}_{3}$ stored in soil at time, $\mathrm{t}=0\left(\mathrm{~kg} \mathrm{~N} \mathrm{~km}^{-2}\right)$;

$x_{4,0}=\mathrm{NO}_{3}$ stored in groundwater, $\mathrm{t}=0\left(\mathrm{~kg} \mathrm{~N} \mathrm{~km}^{-2}\right)$;

$x_{5,0}=\mathrm{NH}_{4}$ stored in soil, $\mathrm{t}=0\left(\mathrm{~kg} \mathrm{~N} \mathrm{~km}^{-2}\right)$;

$x_{6,0}=\mathrm{NH}_{4}$ stored in groundwater, $\mathrm{t}=0\left(\mathrm{~kg} \mathrm{~N} \mathrm{~km}^{-2}\right)$.

The user supplies all the initial values as input.

The N mass-balance for each land use in each reach is calculated as:

$$
\text { Bal }=\text { Initial }+ \text { Input }- \text { Output }- \text { Storage }
$$

Thus, if mass-balance is achieved then the balance will equal zero.

The water balance was expressed as

$$
\mathrm{Bal}_{w}=x_{29,0, i}+x_{30}-x_{31}-x_{29}
$$

where $x_{29,0, i}$ is the initial volume of reach, $i$, and all the other terms are as previously defined.

\section{Appendix C}

DRY DEPOSITION CALCULATION

Daily wet deposition is related to actual precipitation:

$$
\text { WDep }_{t}=\frac{U_{6, t}}{\sum_{t=1}^{t=n} U_{6, t}} T o t_{-} \text {WDep }
$$

where

WDep ${ }_{t}$ is the wet deposition $\left(\mathrm{kg} \mathrm{N} \mathrm{ha}^{-1}\right.$ day $\left.^{-1}\right)$,

$U_{6, t}$ is the actual daily precipitation at time, $\mathrm{t}(\mathrm{mm})$, $n$ is the number of days in year

Tot_WDep is the annual wet deposition $\left(\mathrm{kg} \mathrm{N} \mathrm{ha}^{-1}\right.$ year $\left.^{-1}\right)$

Dry $\mathrm{N}$ deposition is stored in a compartment on days when there is no precipitation. This dry $\mathrm{N}$ storage is added to the soil box when there is a rainfall event, and is expressed as follows:

$$
\begin{aligned}
& \text { IF Act_Prec }(\mathrm{t})=0 \text { THEN } \\
& \text { Dry_Stor }(\mathrm{t})=\text { Dry_Stor }(\mathrm{t}-1)+\text { Dry_Dep }(\mathrm{t}) \\
& \text { Dry_Input }(\mathrm{t})=0
\end{aligned}
$$

ELSE

Dry_Stor $(\mathrm{t})=0$ AND Dry_Input $(\mathrm{t})=$ Dry_Stor $(\mathrm{t}-1)+$

Dry_Dep(t).

where

Dry_Store $(\mathrm{t})$ is the dry deposition stored on leaves $(\mathrm{kg} \mathrm{N}$ $\mathrm{ha}^{-1}$ day $^{-1}$ ),

Dry_Dep(t) is the dry deposition $\left(\mathrm{kg} \mathrm{N} \mathrm{ha}^{-1}\right.$ day $\left.^{-1}\right)$,

Dry_Input(t) is the dry deposition transferred to the soil from the store $\left(\mathrm{kg} \mathrm{N} \mathrm{ha}^{-1} \mathrm{day}^{-1}\right)$. 


\section{Appendix D:}

INCA KENNET INPUT PARAMETERS:

Table D.1 Reach details for the application of INCA to the Kennet system. BFI is the base flow index and the concentrations of $\mathrm{NO}_{3}$ and $\mathrm{NH}_{4}$ and the associated discharge relate to the effluent inputs in each reach.

\begin{tabular}{|c|c|c|c|c|c|}
\hline Reach & Length $(m)$ & $B F I$ & $\mathrm{NO}_{3}\left(m g N l^{-1}\right)$ & $\mathrm{NH}_{4}\left(m g \mathrm{Nl}^{-1}\right)$ & Flow $\left(m^{3} s^{-1}\right)$ \\
\hline 1. Source & 6250 & 0.95 & 0.0 & 0.0 & 0.000 \\
\hline 2. Avebury & 4500 & 0.95 & 0.0 & 0.0 & 0.000 \\
\hline 3. Fyfield & 8000 & 0.95 & 15.8 & 0.7 & 0.060 \\
\hline 4. Clatford & 1750 & 0.95 & 0.9 & 0.0 & 0.060 \\
\hline 5. Marlborough Gauging Station & 3000 & 0.95 & 9.7 & 0.0 & 0.060 \\
\hline 6. Glebe House & 2250 & 0.95 & 0.0 & 0.0 & 0.000 \\
\hline 7. Mildenhall & 500 & 0.95 & 6.4 & 0.1 & 0.060 \\
\hline 8. Stitchcombe & 1500 & 0.95 & 0.0 & 0.0 & 0.000 \\
\hline 9. Axford & 1000 & 0.95 & 0.0 & 0.0 & 0.000 \\
\hline 10. Ramsbury & 4000 & 0.95 & 0.0 & 0.0 & 0.000 \\
\hline 11. Knighton Gauging Station & 2500 & 0.95 & 0.0 & 0.0 & 0.000 \\
\hline 12. Chiltern & 3500 & 0.92 & 4.8 & 0.1 & 0.060 \\
\hline 13. Hungerford & 1750 & 0.92 & 15.7 & 0.0 & 0.060 \\
\hline 14. Hampstead & 10000 & 0.92 & 0.0 & 0.0 & 0.000 \\
\hline 15. Newbury Gauging Station & 4000 & 0.92 & 0.0 & 0.0 & 0.000 \\
\hline 16. Newbury & 1750 & 0.87 & 7.6 & 0.3 & 0.010 \\
\hline 17. Thatcham & 4500 & 0.87 & 0.0 & 0.0 & 0.000 \\
\hline 18. Woolhampton & 5000 & 0.87 & 12.0 & 0.0 & 0.060 \\
\hline 19. Padworth & 4000 & 0.87 & 4.9 & 0.2 & 0.060 \\
\hline 20. Ufton Bridge & 3000 & 0.87 & 0.0 & 0.0 & 0.000 \\
\hline 21. Theale Gauging Station & 3250 & 0.87 & 0.0 & 0.0 & 0.000 \\
\hline 22. Burghfield & 3250 & 0.87 & 0.0 & 0.0 & 0.000 \\
\hline 23. Fobney & 2000 & 0.87 & 0.0 & 0.0 & 0.000 \\
\hline 24. Berkerley Road, Reading & 2250 & 0.87 & 0.0 & 0.0 & 0.000 \\
\hline 25. Confluence with Thames & 2250 & 0.87 & 0.0 & 0.0 & 0.000 \\
\hline
\end{tabular}

Table D.2 The area and the percentage of the different land uses within each reach where: (1) Forest; (2) short vegetation, ungrazed and unfertilised; (3) short vegetation, grazed and unfertilised; (4) short vegetation, grazed and fertilised; (5) arable; and (6) urban.

\begin{tabular}{llllllll}
\hline Reach & Area $\left(\mathrm{km}^{2}\right)$ & $(1) \%$ & $(2) \%$ & $(3) \%$ & $(4) \%$ & $(5) \%$ & $(6) \%$ \\
\hline 1. Source & 24 & 0 & 0 & 13 & 4 & 83 & 0 \\
2. Avebury & 34 & 0 & 0 & 0 & 3 & 97 & 0 \\
3. Fyfield & 51 & 2 & 0 & 0 & 10 & 88 & 0 \\
4. Clatford & 1 & 0 & 0 & 0 & 0 & 100 & 0 \\
5. Marlborough Gauging Station & 24 & 13 & 0 & 4 & 13 & 62 & 8 \\
6. Glebe House & 77 & 1 & 0 & 0 & 4 & 92 & 3 \\
7. Mildenhall & 1 & 0 & 0 & 0 & 0 & 100 & 0 \\
8. Stitchcombe & 2 & 0 & 0 & 0 & 50 & 50 & 0 \\
9. Axford & 2 & 0 & 0 & 0 & 50 & 50 & 0 \\
10. Ramsbury & 24 & 4 & 0 & 0 & 4 & 88 & 4 \\
11. Knighton Gauging Station & 57 & 2 & 0 & 0 & 4 & 92 & 2 \\
12. Chiltern & 13 & 0 & 0 & 8 & 0 & 92 & 0 \\
13. Hungerford & 6 & 0 & 0 & 0 & 17 & 83 & 0 \\
14. Hampstead & 208 & 12 & 0 & 7 & 7 & 73 & 1 \\
15. Newbury Gauging Station & 18 & 0 & 0 & 17 & 33 & 22 & 28 \\
16. Newbury & 266 & 4 & 0 & 8 & 3 & 83 & 2 \\
17. Thatcham & 18 & 11 & 0 & 17 & 17 & 22 & 33 \\
18. Woolhampton & 12 & 8 & 0 & 8 & 25 & 59 & 0 \\
19. Padworth & 159 & 17 & 0 & 21 & 18 & 43 & 1 \\
20. Ufton Bridge & 13 & 0 & 0 & 77 & 8 & 15 & 0 \\
21. Theale Gauging Station & 23 & 13 & 0 & 35 & 9 & 39 & 4 \\
22. Burghfield & 5 & 0 & 0 & 20 & 0 & 20 & 60 \\
23. Fobney & 2 & 0 & 0 & 0 & 0 & 0 & 100 \\
24. Berkerley Road, Reading & 95 & 8 & 0 & 40 & 4 & 31 & 17 \\
25. Confluence with Thames & 3 & 0 & 0 & 0 & 0 & 0 & 100 \\
\hline
\end{tabular}




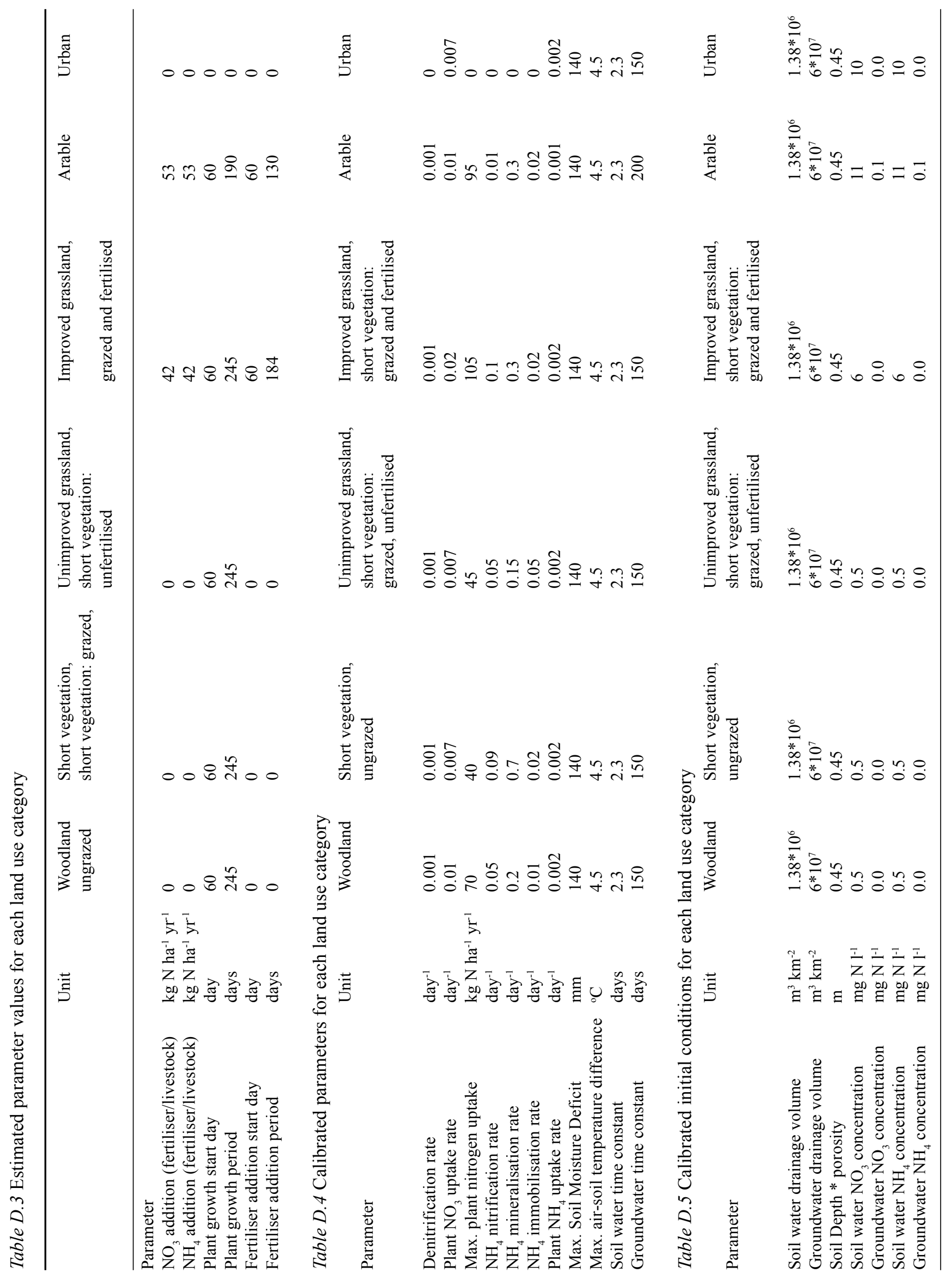

